\title{
THE BIRTH TORTS: \\ DAMAGES FOR WRONGFUL BIRTH AND WRONGFUL LIFE
}

\section{DeAN STRETton}

\begin{abstract}
[This article examines the capacity of parents of children (whether disabled or not) born as a result of medical negligence to sue for the costs associated with the birth and raising of the children ('wrongful birth'), as well as the capacity of disabled children who owe their existence to medical negligence to sue for the costs associated with the disability ('wrongful life'). Many legal systems have allowed the first type of claim, but very few have allowed the second type. The author argues that allowing both types of claim is consistent with ordinary principles of tort law, and that there are no policy reasons that override this conclusion. Consequently, a range of damages ought to be available in relation to both types of claim.]
\end{abstract}

\section{INTRODUCTION}

In July 2003, the High Court of Australia held by a 4:3 majority that where an unplanned child is born through medical negligence, the parents may sue the negligent doctor to recover the costs of raising the child to maturity. ${ }^{1}$ Acting Prime Minister of Australia John Anderson denounced the decision as "repug-

\footnotetext{
*BA(Hons), LLB(Hons) (ANU). Address for correspondence: dean_stretton @ hotmail.com. The author (who is responsible for any errors or omissions in this article) wishes to thank Professor Jim Davis and Dr Joachim Dietrich of the ANU Faculty of Law for helpful comments on an earlier version of this article.

${ }^{1}$ Cattanach v. Melchior, (2003) 199 ALR 131; [2003] HCA 38 (High Court of Australia, 2003).
} 
nant", claiming it "devalue[d]...life" and treated "vulnerable children" as "mere commodities". ${ }^{2}$

In April 2004, the NSW Court of Appeal held by a 2:1 majority that where a disabled child owes his or her existence to an act of medical negligence, the child cannot sue the negligent doctor to recover the costs associated with the disability. ${ }^{3}$ An appeal to the High Court has been foreshadowed. ${ }^{4}$

These cases involve the 'birth torts': wrongful birth and wrongful life respectively. The subject of this paper is whether Australian courts, based on established principles of tort law, should award damages for these torts. Three issues arise for each tort. First, what are the options for recovery of damages? In other words, what heads of damages (if any) might be held to be recoverable for wrongful birth or wrongful life? Second, what heads of damages (if any) would be recoverable under 'normal' tort principles-that is, principles not invoking broad considerations of public policy? Third, are there persuasive policy grounds for choosing an option other than that reached through normal principles?

Part II discusses wrongful birth. It will be argued that 'pregnancy costs' and 'upbringing costs' (in the sense to be defined) are recoverable on normal principles, and that the policy arguments for other options are unpersuasive. Part III discusses wrongful life. It will be argued that damages for pain, suffering and 'disability costs' are recoverable on normal principles, and that the policy arguments for other options are, again, weak. Damages for the birth torts should thus be awarded.

\section{WRONGFUL BIRTH}

\section{A Definitions and Approaches}

\section{$1 \quad$ Wrongful birth defined}

Wrongful birth occurs where an act of medical negligence causes the birth of an unplanned child. The child may be 'healthy' (non-disabled) or disabled. The negligence may involve a doctor's failure to:

\footnotetext{
2 John Anderson, Cattanach Decision: Statement by the Acting Prime Minister (Press Release, 17 July 2003), <http://www.ministers.dotars.gov.au/ja/releases/2003/july/a80_2003.htm> (last visited Mar. 8 , 2005).

3 Harriton v. Stephens; Waller v. James; Waller v. Hoolahan, (2004) NSWCA 93 (NSW Court of Appeal, 2004) (Spigelman CJ and Ipp JA; Mason P dissenting).

M Pelly, Sydney Morning Herald, Tougher Limits on Suing Doctors, 30 April 2004, <http:// www.smh.com.au/articles/2004/04/29/1083224520781.html > (last visited Mar. 8, 2005).

5 Laura Hoyano, Misconceptions about Wrongful Conception, 65 MODERN L.REV. 883, 886 n. 26 (2002); see also: JOHN SEYMOUR, CHILDBIRTH AND THE LAW ch 5 (2000).
} 
(a) warn of the risk that a competently performed sterilisation may naturally reverse or otherwise fail; so that the plaintiffs, unaware of that risk, cease using contraception;

(b) diagnose or advise of pregnancy, where diagnosis or advice would have led to lawful ${ }^{6}$ termination;

(c) diagnose a condition in either the parents or the foetus that will cause the child to be disabled, where diagnosis would have led to effective contraception or lawful termination;

(d) take reasonable care in performing an attempted sterilisation or abortion; or

(e) take reasonable care in giving advice on, or supplying, contraceptives.

Each of (a)-(e) creates a risk that an unplanned pregnancy will occur or continue. If the risk eventuates, and the pregnancy is carried to term-because pregnancy was discovered too late to terminate safely or legally, or because the plaintiffs feel morally or emotionally unable to terminate-then wrongful birth has occurred.

In a wrongful birth action, the parent or parents sue the doctor in negligence in respect of the damage resulting from the pregnancy and birth. The damage may include:

(i) pregnancy costs: the pain, suffering and economic loss associated with pregnancy, including labour pains, medical bills, maternity clothes, loss of income during pregnancy, and (less commonly) the cost of moving or extending the house in anticipation of accommodating an extra member; and

(ii) upbringing costs: the costs of raising the child from birth to maturity or independence, including amounts spent on food, clothes, education, presents and entertainment; plus loss of income through looking after the child, and (if this occurs after birth) the cost of moving or extending house to accommodate an extra member. ${ }^{7}$

\footnotetext{
${ }^{6}$ See: Medical Practitioners Act, 1930, ss55A-55E (ACT) ; Crimes Act, 1900, ss82-84 (NSW) ; Criminal Code Act, 1983, ss172-174 (NT); Criminal Code Act, 1899, ss224-226 (Qld); Criminal Law Consolidation Act, 1935, ss81-82A (SA); Criminal Code Act, 1924, ss134-135 (Tas) ; Crimes Act, 1958, ss65-66 (Vic); Health Act, 1911, s334 (WA). See also: R v. Wald, (1971) 3 DCR (NSW 25 (District Court of NSW, 1971); R v. Davidson (1969) VR 667 (Supreme Court of Victoria, 1969); CES v. Superclinics (Australia) Pty Ltd (1995) 38 NSWLR 47 (NSW Supreme Court, 1995) . If the termination would not have been lawful, the defendant may rely on the defence of illegality; see Superclinics.

${ }^{7}$ In addition to pregnancy and upbringing costs, the father can apparently recover for 'loss of consortium'; see Cattanach v. Melchior [2003] 199 ALR 131; [2003] HCA 38, [14]-[15] (High Court of Australia, 2003). This is an award of damages 'for all practical, domestic disadvantages suffered by a husband in consequence of the impair[ment, during or after pregnancy, of the] health or bodily condition of his wife':; see Toohey v. Hollier [1955] 92 CLR 618 (High Court of Australia, 1955). The viability of claims for loss of consortium was not on appeal in Cattanach, but Gleeson CJ appeared doubtful, noting 'such claims are now anomalous, and bear a proprietorial character inconsistent with current ideas as to the relationship between husband and wife':
} 
The terms 'wrongful birth', 'wrongful pregnancy' and 'wrongful conception' have been variously defined, sometimes interchangeably. ${ }^{8}$ Here, only 'wrongful birth' is used, and has the meaning given above. Strictly, what is 'wrongful' is the negligence, not the birth; ${ }^{9}$ but the label is a convenient shorthand.

\section{Options for recovery of damages}

The reasonable options for recovery of damages are generally considered to be: ${ }^{10}$

(1) full recovery without set-off: upbringing and pregnancy costs can be awarded whether the child is healthy or disabled; and damages are not reduced for any emotional benefits the child will bring to the parents (but may perhaps be reduced for any financial benefits the child will bring, such as statutory welfare benefits).

(2) full recovery with set-off: as for full recovery, but damages are reduced (offset) for any emotional benefits the child will bring.

(3) pregnancy and extra disability costs only: pregnancy costs can be awarded; upbringing costs can be awarded, but only where either the child, or perhaps a parent, is disabled, and limited to the extra costs attributable to the disability ('extra' compared to the cost for a non-disabled person).

(4) pregnancy costs only: pregnancy costs can be awarded; upbringing costs cannot be awarded, even if the child is disabled.

(5) no recovery: neither pregnancy nor upbringing costs can be awarded.

\section{Existing authorities: UK, US and Canada}

In the UK, the first reported wrongful birth case allowed recovery of pregnancy costs. ${ }^{11}$ Lower courts initially disallowed recovery of upbringing costs for policy reasons, ${ }^{12}$ but later allowed recovery with no offset for healthy, ${ }^{13}$ dis-

\footnotetext{
${ }^{8}$ See: Cattanach v. Melchior ([2003)] 199 ALR 131; [2003] HCA 38, [285] (Callinan J)High Court of Australia, 2003) ; McFarlane v. Tayside Health Board [1999] 4 All ER 961 (House of Lords, 1999); [2000] 2 AC 59, 76G (Court of Appeal, England, 2000)(Lord Steyn), 91G-92A (Lord Hope), 99B-C (Lord Clyde); Kealey v. Berezowski ([1996)] 136 DLR (4th) 708 (Ontario Court, General Division), 723f-724d (Lax J); L Hoyano, Misconceptions about Wrongful Conception, 65 MODERN L. REV. 883906, 884 (2002); A Maclean, 'McFarlane v Tayside Health Board: A Wrongful Conception in the House of Lords?' Web Journal of Current Legal Issues [2000] 3 Web JCLI [s 1]

<http://webjcli.ncl.ac.uk/2000/issue3/maclean3.html>.(last visited 8 March 2005).

9 Cattanach v. Melchior [2003] 199 ALR 131; [2003] HCA 38, (High Court of Australia, 2003) [57], [68] (McHugh and Gummow JJ), [193] (Hayne J); SEYMOUR, supra note 5, at 75.

${ }_{10}$ Cattanach v. Melchior [2003] 199 ALR 131; [2003] HCA 38, (High Court of Australia, 2003) [138] (Kirby J); see also Melchior v. Cattanach [2001] QCA 246, (Queensland Court of Appeal,2001) [151] (Thomas JA).

${ }^{11}$ Scuriaga v. Powell [1979] 123 SJ 406 (QBD).

12 Udale v. Bloomsbury Health Authority [1983] All ER 522 (House of Lords, 1983); [1983] 1 WLR 1098 (QBD).
} 
abled, ${ }^{14}$ and temporarily disabled ${ }^{15}$ children-extending even to the costs of private education ${ }^{16}$ and upbringing past age $18 .^{17}$ In McFarlane, the House of Lords cast aside this lower-court authority and held-largely through unsupported intuitions on what is "fair, just and reasonable" ${ }^{18}$ - that upbringing costs for a healthy child are not recoverable. Lower courts have since confined McFarlane to allow the extra upbringing costs attributable to a child's ${ }^{19}$ or mother' ${ }^{20}$ disability. However, in Rees-another morass of unsupported intuitions-the House of Lords held by majority that the mother's extra disability costs are not recoverable ${ }^{21}$ (though a different majority held, obiter, that extra costs attributable to the child's disability are recoverable ${ }^{22}$ ). In an admitted 'gloss ${ }^{23}$-an arbitrary and unprincipled exception to the policy in McFarlane ${ }^{24}$-Rees also held that wrongful birth parents may recover a nominal sum of $£ 15,000$ for violation of their autonomy. ${ }^{25}$ The UK thus allows recovery of pregnancy costs and the extra costs attributable to the child's disability.

US decisions are numerous and divergent because the birth torts are a state rather than federal matter. Some states permit full recovery with $^{26}$ or without ${ }^{27}$ offset.

\footnotetext{
13 Thake v. Maurice [1986] 1 QB 644; [1986] 1 All ER 497 (CA) (Court of Appeal, 1986); Allen v. Bloomsbury Health Authority [1993] 1 All ER 651 (House of Lords, 1993); (1992) 13 BMLR 47 (Queens Bench Division); Fish v. Wilcox [1994] 5 Med LR 230 (CA).

${ }_{14}$ Emeh v. Kensington and Chelsea and Westminster Area Health Authority [1985] 1 QB 1012; [1984] 3 All ER 1044 (CA).

${ }^{15}$ Robinson v. Salford Health Authority [1992] 3 Med LR 270 (QBD).

${ }_{16}$ Benarr v. Kettering Health Authority [1988] 138 NLJ 179 (QBD).

17 Nunnerley v. Warrington Health Authority [2000] Lloyd's Rep Med 170 (QBD); Taylor v. Shropshire Health Authority [2000] Lloyd's Rep Med 96 (QBD). But see also claims denied for causation reasons: Salih v. Enfield Health Authority [1991] 3 All ER 400 (CA); R v. Croydon Health Authority [1998] Lloyd's Rep Med 44 (CA).

${ }_{18}$ McFarlane v. Tayside Health Board [1999] 4 All ER 961; [2000] 2 AC 59 (UK House of Lords, 2000), 76C (Lord Slynn), 83D-E (Lord Steyn), 97C (Lord Hope). Applied in Greenfield v Irwin [2001] 1 WLR 1279 (CA).

${ }_{19}$ Rand v. East Dorset Health Authority [2000] Lloyd's Rep Med 181 (QBD); Hardman v Amin [2000] Lloyd's Rep Med 498 (QBD); Parkinson v St James and Seacroft University Hospital NHS Trust [2001] EWCA Civ 530; [2001] 3 All ER 97; Groom v Selby [2001] Lloyd's Rep Med 39 (QBD).

${ }^{20}$ Rees v. Darlington Memorial Hospital NHS Trust [2002] EWCA Civ 88; [2002] All ER 177 (House of Lords, 2002)).

${ }_{21}$ Rees v. Darlington Memorial Hospital NHS Trust [2003] UKHL 52, [9] (House Of Lords, 2003) (Lord Bingham), [18] (Lord Nicholls), [114] (Lord Millett), [143] (Lord Scott); [39] (Lord Steyn), [68] (Lord Hope), [96]-[98] (Lord Hutton), dissenting.

22 Rees v. Darlington Memorial Hospital NHS Trust [2003] UKHL 52, (House of Lords, 2003) [35] (Lord Steyn), [57] (Lord Hope), [91] (Lord Hutton), [112] (Lord Millett); [9] (Lord Bingham), [18] (Lord Nicholls), [145] (Lord Scott), dissenting.

${ }^{23}$ Rees v. Darlington Memorial Hospital NHS Trust [2003] UKHL 52, (House of Lords, 2003) [7] (Lord Bingham), [17] (Lord Nicholls).

${ }_{24}$ See: Rees v. Darlington Memorial Hospital NHS Trust [2003] UKHL 52, (House of Lords, 2003) [40]-[47] (Lord Steyn), [70]-[77] (Lord Hope); Cattanach v. Melchior [2003] 199 ALR 131; [2003] HCA 38 (High Court of Australia, 2003), [91] (McHugh and Gummow JJ), [165] (Kirby J).

${ }^{25}$ Rees v. Darlington Memorial Hospital NHS Trust [2003] UKHL 52, (House of Lords, 2003) [8] (Lord Bingham), [17] \& [19] (Lord Nicholls), [123]-[125] (Lord Millett), [148] (Lord Scott).

${ }_{26}$ Arizona (University of Arizona Health Sciences Center v. Superior Court 667 P2d 1294, 1299 [1983]); Connecticut (Ochs v. Borelli 445 A 2d 883, 886 [1982]); Minnesota (Sherlock v. Stillwater Clinic 260 NW 2d 169, 175-76 [1977]).
} 
A majority disallow recovery of upbringing costs where the child is healthy, ${ }^{28}$ but some allow recovery of extra disability costs. ${ }^{29}$

Canadian courts have largely mirrored the UK, but with some variation among jurisdictions. Lower courts initially disallowed recovery of upbringing costs for policy reasons, ${ }^{30}$ but subsequent cases awarded pregnancy and upbringing costs for healthy children (with an offset for emotional benefits ${ }^{31}$ ) and for disabled children $^{32}$ (though in some cases this was limited to the extra costs attributable to the child's disability ${ }^{33}$ ). More recently, however, lower courts have held that upbringing costs for a healthy child can only be awarded where the parents had decided for financial reasons to have no further children; ${ }^{34}$ or have held that such costs should not be awarded at all. ${ }^{35}$ The law regarding healthy children is thus uncertain. For disabled children, the Supreme Court of Canada accepted (obiter,

${ }^{27}$ California [Custodio v. Bauer 251 Cal.App 2d 303, 59 Cal.Rptr 463 [1967]); New Mexico (Lovelace Medical Center v. Mendez 805 P 2d 603 [1991]); Oregon (Zehr v. Haugen 871 P 2d 1006 [1994]); Wisconsin (Marciniak v. Lundborg 450 N.W.2d 243 [1990]).

${ }^{28}$ Including: Alabama (Boone v. Mullendore 416 So 2d 718 [1982]); Alaska (M.A. v. United States 951 P 2d 851 [1998]); Arkansas (Wilbur v. Kerr 628 SW 2d 568 [1982]); District of Columbia (Flowers v. District of Columbia 478 A 2d 1073 [1984]); Florida (Fassoulas v. Ramey 450 So 2d 822 [1984]); Georgia (Atlanta Obstetrics \& Gynecology Group v. Abelson 398 SE 2d 557 [1990]); Illinois (Cockrum v. Baumgartner 447 NE 2d 385 [1983], cert denied, 464 U.S. 846, 104 S.Ct. 149, 78 L.Ed 2d 139 (1983)); Iowa (Nanke v. Napier 346 NW 2d 520 [1984]); Kansas (Johnston v. Elkins 736 P 2d 935 [1987]); Kentucky (Schork v. Huber 648 SW 2d 861 [1983]); Louisiana (Pitre v. Opelousas General Hospital 530 So 2d 1151 [1988]); Maine (Macomber v. Dillman 505 A 2d 810 [1986]); Michigan (Rouse v. Wesley 494 NW 2d 7 [1992]); Missouri (Girdley v. Coats 825 S.W 2d 295 [1992]); Nebraska (Hitzemann v. Adam 518 NW 2d 102 [1994]); Nevada (Szekeres v. Robinson 715 P 2d 1076 [1986]); New Hampshire (Kingsbury v. Smith 442 A 2d 1003 [1982]); New Jersey (Gracia v. Meiselman 531 A 2d 1373 [1987] (obiter)); New York (O'Toole v. Greenberg 477 NE 2d 445 [1985]); North Carolina (Jackson v. Bumgardner 347 SE 2d 743 [1986]); Ohio (Johnson v. University Hospitals of Cleveland 540 NE 2d 1370 [1989]); Oklahoma (Wofford v. Davis 764 P 2d 161 [1988]); Pennsylvania (Butler v. Rolling Hill Hospital 582 A 2d 1384 [1990]); Rhode Island (Emerson v. Magendantz 689 A 2d 409 [1997]); Tennessee (Smith v. Gore 728 SW 2d 738 [1987]); Texas (Terrell v. Garcia 496 SW 2d 124 [1973]); Utah (C.S. v. Nielson 767 P 2d 504 (N[1988]); Virginia (Miller v. Johnson 343 SE 2d 301 [1986]); Washington (McKernan v. Aasheim 687 P 2d 850 [1984)]; West Virginia (James G. v. Caserta 332 SE 2d 872 [1985]); Wyoming (Beardsley v. Wierdsma 650 P 2d 288 [1982]). Authorities collected in: Chaffee v Seslar (Unreported, Indiana Supreme Court, 15 April 2003),

<http://www.marciaoddi.com/cgi-local/blogdocs/Chaffee.pdf> (last visited 8 March 2005).

${ }^{29}$ See: Bader v. Johnson 675 NE 2d 1119 (Indiana Court of Appeal, 1997).

${ }^{30}$ Colp v. Ringrose ([1976)] 3 L Med Q 72 (Aberta SCTD) (obiter); Doiron v. Orr ([1978)] 86 DLR (3d) 719 (Ontario HC); Cataford v. Moreau ([1978)] 114 DLR (3d) 585 (Québec SC) (obiter). See also Keats v. Pearce ([1984)] 48 Nfld \& PEIR 102 (Newfoundland SCTD) (upbringing costs disallowed because plaintiff could have mitigated losses through abortion); Fredette v. Wiebe ([1986)] 29 DLR (4th) 534, 4 BCLR (2d) 184 (SC) (upbringing costs disallowed because plaintiff would have had children and incurred those costs anyway).

${ }^{31}$ Suite v. Cooke [1993] RJQ 514, 15 CCLT (2d) 15 (SC), affirmed [1995] RJQ 2765 (CA).

${ }^{32}$ Joshi v Wooley [1995] 4 BCLR (3d) 208 (SC).

${ }^{33}$ Cherry v. Borsman ([1990)] 75 DLR (4th) 668 (SC), varied (1992) 94 DLR (4th) 487 (CA)

34 Kealey v Berezowski [1996] 136 DLR (4th) 708 (Ontario Court, General Division); MS v. Baker [2001] ABQB 1032, [2002] 4 WWR 487 (obiter).

35 Mummery v. Olsson [2001] OJ No 226 (Ontario Superior Court of Justice); MYv Boutros [2002] ABQB 362, 11 CCLT (3d) 271; Bevilacqua v. Altenkirk [2004] BCSC 945 (awarded damages for pain, suffering and inconvenience, but no pecuniary damages); Roe v. Dabbs [2004] BCSC 957 (awarded damages for pain, suffering, inconvenience, and loss of income during pregnancy, but no other pecuniary damages). 
since the point was not on appeal) that plaintiffs can recover pregnancy costs and the extra upbringing costs attributable to the child's disability-though the latter are discounted according to the probability of those costs being borne by the state. $^{36}$

\section{$4 \quad$ Existing authorities: Australia}

Before Cattanach, ${ }^{37}$ wrongful birth was considered in NSW and Queensland. In NSW, damages were awarded for pregnancy costs but not upbringing costs, since the plaintiff's choice to keep the child rather than adopt it out allegedly severed causation between the negligence and upbringing costs. ${ }^{38}$ In Queensland, full recovery was permitted through an application of normal principles and rejection of opposing policy arguments. ${ }^{39}$

In Cattanach, a sterilisation was performed on only one fallopian tube, since the mother falsely believed her other tube had been removed as a child. The sterilising doctor negligently failed to warn that the mother should have this belief checked (if it were false, she could still conceive). ${ }^{40}$ As a result the plaintiffs ceased using contraception, thinking they could not conceive, and-because the second tube was in fact present-a healthy son was later conceived and born. The parents sued the sterilising doctor and the State of Queensland (the latter as responsible for the hospital where the sterilisation occurred). Pregnancy and upbringing costs were awarded at first instance ${ }^{41}$ and upheld on appeal. ${ }^{42}$ On further appeal, the High Court confirmed that upbringing costs are recoverable. ${ }^{43}$ Pregnancy costs were not on appeal, but the absurdity of allowing upbringing costs without pregnancy costs makes full recovery the de facto position.

\footnotetext{
${ }^{36}$ Krangle v. Brisco [2002] 1 SCR 205 (Supreme Court of Canada). The Court disallowed upbringing costs past the age of majority (19), since those costs (given the facts and British Columbia legislation) would be borne by the state, not the parents. Krangle was followed in: Zhang v. Kan [2003] BCJ No 164; [2003] BCSC 5 (extra disability costs awarded to age 45 but discounted by $70 \%$ because the state would likely bear those costs); and Jones v. Rostvig [2003] BCJ No 1840; [2003] BCSC 1222 (extra disability costs awarded to age 25 , when the court expected the son to move into a state-funded group home).

${ }^{37}$ Cattanach v. Melchior, (2003) 199 ALR 131; [2003] HCA 38 (High Court of Australia, 2003). Useful summary and analysis is given in: J Seymour, Cattanach $v$ Melchior: Legal Principles and Public Policy 11(3) Torts LJ 208 (2003); and P Phillips, Medical Negligence and Wrongful Birth: Cattanach v Melchior - A Discussion of the Medical, Legal and Policy Issues, 15(3) INSURANCE L.J. 203 (2004).

${ }^{38}$ CES v. Superclinics (1995) 38 NSWLR 47 (NSW Supreme Court, 1995).

39 Dahl v. Purnell (1992) 15 Qld Lawyer Reps 33 (healthy child); Veivers v. Connolly [1995] 2 Qd.R 326 (Townsville SC) (disabled child); Melchior v Cattanach [2000] QSC 285; (2001) Aust Torts Reports I81-597 (Queensland Supreme Court, 2001) (healthy child); Melchior v Cattanach [2001] QCA 246 (Queensland Court of Appeal, 2001); see also Murray v Whiting [2002] QSC 257 (Queensland Supreme Court, 2002).

${ }^{40}$ Cattanach v. Melchior, (2003) 199 ALR 131; [2003] HCA 38 (High Court of Australia, 2003) [11][12] (Gleeson CJ).

Melchior v. Cattanach, [2000] QSC 285; (2001) Aust Torts Reports 9]81-597 (Queensland Supreme Court, 2000).

${ }^{42}$ Melchior v. Cattanach [2001] QCA 246 (QLD Court of Appeal).

${ }^{43}$ Cattanach v. Melchior, (2003) 199 ALR 131; [2003] HCA 38 (High Court of Australia, 2003)
} 
The Cattanach majority held that upbringing costs are recoverable on normal principles; ${ }^{44}$ that there should be no set-off between financial costs and emotional benefits, since these affect different interests ${ }^{45}$ and that the policy arguments against full recovery are unpersuasive.

McHugh and Gummow JJ appeared to treat the plaintiffs' loss as pure economic loss, stating 'the relevant damage suffered by the [plaintiffs] is the expenditure that they have incurred or will incur in the future, 46 (though they suggested the outcome did not depend on this classification ${ }^{47}$ ). They noted the danger of relying on policy arguments ${ }^{48}$ that are empirically unfounded or that slide impermissibly from broad statements of widely held values to the conclusion that upbringing costs are unrecoverable. ${ }^{49}$ Kirby J characterised the plaintiffs' economic loss not as pure but as consequential upon the physical damage of unwanted pregnancy. ${ }^{50}$ He noted that policy arguments against full recovery, including those of the Cattanach minority, ${ }^{51}$ rely on controversial values, unsupported assumptions, or are legally irrelevant. Callinan J held the plaintiffs' economic loss was pure rather than consequential, ${ }^{52}$ but saw the case as 'a relatively simple one ${ }^{53}$ where the requirements for recovery of pure economic loss are met and the opposing policy arguments are weak: ${ }^{54}$ a judge's 'distaste' cannot override legal principle. ${ }^{55}$ The majority also warned that a new form of

${ }^{44}$ Cattanach v. Melchior, (2003) 199 ALR 131; [2003] HCA 38 (High Court of Australia, 2003), [51] \& [71]-[72] (McHugh and Gummow JJ), [176] \& [179] (Kirby J), [299] (Callinan J). See also: Melchior v. Cattanach [2001] QCA 246, (QLD Court of Appeal, 2001) [83] (Davies JA); McFarlane v. Tayside Health Board [1999] 4 All ER 961 (House of Lords, 1999); [2000] 2 AC 59, 74C-D (UK House of Lords, 2000) (Lord Slynn), 82E \& 84C-E (Lord Steyn), 107B-C (Lord Millett); Parkinson v. St James and Seacroft University Hospital NHS Trust [2001] EWCA Civ 530; [2001] 3 All ER 97, 118b-c (Hale LJ); Rees v. Darlington Memorial Hospital NHS Trust [2002] EWCA Civ 88; [2002] All ER 177, 189b (Waller LJ); Emeh v Kensington and Chelsea and Westminster Area Health Authority [1985] 1 QB 1012, 1028E-F (Purchas LJ); [1984] 3 All ER 1044 (CA).

45 Cattanach v. Melchior, (2003) 199 ALR 131; [2003] HCA 38 (High Court of Australia, 2003), [87][90] (McHugh and Gummow JJ); [103]-[105] (Kirby J); [297]-[298] (Callinan J).

${ }^{46}$ Cattanach v. Melchior, (2003) 199 ALR 131; [2003] HCA 38 (High Court of Australia, 2003) [67] (McHugh and Gummow JJ).

47 Cattanach v. Melchior, (2003) 199 ALR 131; [2003] HCA 38 (High Court of Australia, 2003), [66] \& [72] (McHugh and Gummow JJ).

${ }^{48}$ For example: Cattanach v. Melchior, (2003) 199 ALR 131; [2003] HCA 38 (High Court of Australia, 2003) [35] (Gleeson CJ); Rees v. Darlington Memorial Hospital NHS Trust [2003] UKHL 52, (House of Lords, 2003) [16] (Lord Nicholls).

49 Cattanach v. Melchior, (2003) 199 ALR 131; [2003] HCA 38 (High Court of Australia, 2003), [77] (McHugh and Gummow JJ).

50 Cattanach v. Melchior, (2003) 199 ALR 131; [2003] HCA 38 (High Court of Australia, 2003), [148] (Kirby J).

51 Cattanach v. Melchior, (2003) 199 ALR 131; [2003] HCA 38 (High Court of Australia, 2003), [149], [151], [154], [176] (Kirby J).

52 Cattanach v. Melchior, (2003) 199 ALR 131; [2003] HCA 38 (High Court of Australia, 2003), [299] $\&$ [302] (Callinan J).

53 Cattanach v. Melchior, (2003) 199 ALR 131; [2003] HCA 38 (High Court of Australia, 2003), [302] (Callinan J).

54 Cattanach v. Melchior, (2003) 199 ALR 131; [2003] HCA 38 (High Court of Australia, 2003), [299] (Callinan J).

55 Cattanach Cattanach v. Melchior, (2003) 199 ALR 131; [2003] HCA 38 (High Court of Australia, 2003), [296] (Callinan J). 
legal immunity would be given to doctors and hospitals if shielded from the consequences of their negligence. ${ }^{56}$

The minority judges assumed, virtually without supporting argument,${ }^{57}$ that damages must be offset for any emotional benefits the child will bring. They held $^{58}$ that financially estimating those benefits, and thus allegedly treating them as a commodity, creates problems of 'legal coherence' ${ }^{59}$ because it runs contrary to the law's assumptions about 'desirable paradigm[s] of family relationships, 60 and 'key values in family life'. ${ }^{6}$

On other matters the minority differed. Gleeson CJ saw the plaintiffs' loss as pure economic loss, ${ }^{62}$ and held that if recovery of upbringing costs were allowed then liability could potentially extend past age 18 to weddings, tertiary education, and so on. ${ }^{63}$ He concluded that liability for upbringing costs would be indeterminate (incapable of calculation or non-arbitrary limitation), and would therefore be denied on normal principles, since normal principles do not permit recovery of indeterminate amounts for pure economic loss. ${ }^{64}$ Hayne $\mathrm{J}$, on the other hand, held the economic loss was consequential ${ }^{65}$ and that normal principles permit recovery. ${ }^{66} \mathrm{He}$ noted that most policy arguments against recovery are weak but he ultimately found the 'paradigms' argument persuasive. ${ }^{67}$

Heydon J did not discuss whether the plaintiffs' economic loss was pure or consequential, or whether normal principles permit recovery, but instead launched a litany of policy arguments against recovery, based largely on the assumption that parents will happily denounce their child or formulate elaborate fictions in order to secure maximum compensation. The overall argument seemed to be that since (as Heydon J thought) most wrongful birth plaintiffs will

\footnotetext{
${ }^{56}$ Cattanach v. Melchior, (2003) 199 ALR 131; [2003] HCA 38 (High Court of Australia, 2003), [59] (McHugh and Gummow JJ), [149] \& [179] (Kirby J), [295] (Callinan J).

${ }^{57}$ But cf Cattanach Cattanach v. Melchior, (2003) 199 ALR 131; [2003] HCA 38 (High Court of Australia, 2003), [37] (Gleeson CJ) (rejecting the 'coal miner' analogy often used to deny there should be any offset; see Part II, B.5, below).

${ }_{58}$ Cattanach v. Melchior, (2003) 199 ALR 131; [2003] HCA 38 (High Court of Australia, 2003), [35] \& [36] \& [38] (Gleeson CJ), [249]-[262] (Hayne J), [306]-[403] (Heydon J).

Cattanach v. Melchior, (2003) 199 ALR 131; [2003] HCA 38 (High Court of Australia, 2003), [35]

(Gleeson CJ).

60 Cattanach v. Melchior, (2003) 199 ALR 131; [2003] HCA 38 (High Court of Australia, 2003), [258] (Hayne J).

61 Cattanach v. Melchior, (2003) 199 ALR 131; [2003] HCA 38 (High Court of Australia, 2003), [322] (Heydon J).

Cattanach v. Melchior, (2003) 199 ALR 131; [2003] HCA 38 (High Court of Australia, 2003), [9] \& [19] (Gleeson CJ).

63 Cattanach v. Melchior, (2003) 199 ALR 131; [2003] HCA 38 (High Court of Australia, 2003), [32] (Gleeson CJ).

${ }_{64}$ Cattanach v. Melchior, (2003) 199 ALR 131; [2003] HCA 38 (High Court of Australia, 2003), [39] (Gleeson CJ).

${ }^{65}$ Cattanach v. Melchior, (2003) 199 ALR 131; [2003] HCA 38 (High Court of Australia, 2003), [193]

(Hayne J).
${ }_{6}$ Cattanach v Melchior (2003) 199 ALR 131; [2003] HCA 38, (High Court of Australia 2003) [192] (Hayne J)

67 Cattanach v Melchior (2003) 199 ALR 131; [2003] HCA 38 (High Court of Australia, 2003), [195][222] (Hayne J).
} 
act dishonestly and in ways that undermine family values, wrongful birth actions should be disallowed. This was perhaps the weakest Cattanach judgment, since it attempts to override ordinary principles and enforce controversial 'values in family life ${ }^{68}$ by asserting empirically unsupported speculations about the motives and dispositions of potential litigants. It is thus a use of judicial power for 'the furthering of some political, moral or social program' (a program supporting those 'values'), and so exhibits what some would label, and perhaps rightly decry, as 'judicial activism'. 69

It will now be argued that normal principles permit full recovery with no set-off (Section 2); and that there are no persuasive policy grounds for accepting a different option (Section 3). Full recovery is therefore the 'correct', or most defensible, position at law.

\section{B Do Normal Tort Principles Support Recovery for Dam- ages?}

\section{What are 'normal' principles of negligence?}

'Normal' ${ }^{70}$ or "ordinary ${ }^{71}$ tort principles contrast in some way with policy considerations. However, two types of policy consideration are relevant in negligence. First, policy considerations may focus on the actions, events and connections between defendant and potential plaintiffs, and ask whether these make it reasonable to attribute duty of care, breach of duty, causation and remoteness. ${ }^{72}$ Second, policy considerations may go beyond those actions, events and connections and consider, in light of further relationships or social factors, whether attributing liability is socially or morally desirable. ${ }^{73}$ 'Normal' principles appear to be those excluding the second category of policy consideration. ${ }^{74}$

\footnotetext{
${ }^{68}$ Cattanach v. Melchior, (2003) 199 ALR 131; [2003] HCA 38 (High Court of Australia, 2003), [322] (Heydon J).

${ }^{69}$ Dyson Heydon, Judicial Activism and the Death of the Rule of Law, 47 QUADRANT 9-10 (Jan-Feb 2003).

${ }^{70}$ Cattanach v. Melchior, (2003) 199 ALR 131; [2003] HCA 38 (High Court of Australia, 2003),, [149] (Kirby J).

1 Cattanach v. Melchior, (2003) 199 ALR 131; [2003] HCA 38 (High Court of Australia, 2003),, [51] (McHugh and Gummow JJ).

72 Tame v. State of New South Wales; Annetts v. Australian Stations Pty Ltd (2002) 191 ALR 449; [2002] HCA 35, (High Court of Australia, 2002) [27] \& [32] (Gleeson CJ), [53] (Gaudron J), [103] (McHugh J), [239] (Gummow and Kirby JJ), [304] (Hayne J), [358] (Callinan J); March v. E \& MH Stramare Pty Ltd (1991) 171 CLR 506; (1991) 99 ALR 423, (High Court of Australia, 1991) 430-1 (Mason CJ; Gaudron J agreeing), 435-6 (Deane J; Gaudron J agreeing), 436 (Toohey J).

${ }^{73}$ Giannarelli \& Shulkes v. Wraith (1988) 165 CLR 543; (1988) 81 ALR 417 (High Court of Australia, 1988); Gala v. Preston (1991) 172 CLR 243; (1991) 100 ALR 29. (High Court of Australia, 1991). ${ }_{74}$ See also: Melchior v Cattanach [2001] QCA 246, (Queensland Court of Appeal, 2001) [36] (McMurdo P).
} 


\section{$2 \quad$ Normal principles applied to wrongful birth}

On normal principles, a defendant is liable for: (a) physical damage—-damage to person or property - that is reasonably foreseeable, reasonably preventable and caused by his conduct; ${ }^{75}$ and (b) reasonably foreseeable kinds of damage caused by that physical damage. ${ }^{76}$

Assume for now that unwanted pregnancy is physical damage. Concerning (a), unwanted pregnancy involving a healthy or disabled child is reasonably foreseeable, reasonably preventable (say, by warning that sterilisation may reverse), and-in relevant cases-caused by the doctor's conduct (such as failure to warn).

Concerning (b), pregnancy and upbringing costs are reasonably foreseeable kinds of damage flowing from unwanted pregnancy, since they are the very kinds of damage likely to result. Failure to abort or adopt out the child will not sever causation between the breach and upbringing costs, since keeping the child is a foreseeable and non-negligent consequence of the breach $;{ }^{77}$ indeed, failure to abort or adopt out is precisely a failure to interrupt the causal chain. ${ }^{78}$ Nor can failure to abort or adopt out be seen as an unreasonable failure to mitigate damage, since abortion and adoption are sensitive matters of individual conscience and courts are rightly loath to find such failure unreasonable. ${ }^{79}$

Thus, assuming unwanted pregnancy is physical damage, the negligent doctorwhether the child is healthy or disabled-is liable on normal principles for pregnancy and upbringing costs.

\footnotetext{
${ }^{75}$ Wyong Shire Council v. Shirt (1980) 146 CLR 40 (High Court of Australia, 1980); March v. E \& MH Stramare Pty Ltd (1991) 171 CLR 506; (1991) 99 ALR 423 (High Court of Australia, 1991).

${ }_{76}$ Overseas Tankship (UK) Ltd v. Miller Steamship Co Pty Ltd (The Wagon Mound (No2)) [1967] 1 AC 617 (Eng. Court of Appeal, 1967); [1967] ALR 97; [1966] 2 All ER 709; Mahony v. J Kruschich (Demolitions) Pty Ltd (1985) 156 CLR 522; (1985) 59 ALR 722 (High Court of Australia, 1985).

77 See: Mahony v. J Kruschich (Demolitions) Pty Ltd (1985) 156 CLR 522; (1985) 59 ALR 722, (High Court of Australia, 1985) 725-6 (Gibbs CJ, Mason, Wilson, Brennan and Dawson JJ); March v. E \& MH Stramare Pty Ltd (1991) 171 CLR 506; (1991) 99 ALR 423 (High Court of Australia, 1991), 426 \& 4312 (Mason CJ; Toohey and Gaudron JJ agreeing).

${ }_{78}$ Melchior v Cattanach [2000] QSC 285, (Queensland Supreme Court, 2000) [57] (Holmes J); (2001) Aust Torts Reports I81-597 Cattanach v. Melchior, (2003) 199 ALR 131; [2003] HCA 38 (High Court of Australia, 2003),, [161] (Kirby J); McFarlane v. Tayside Health Board [1999] 4 All ER 961; [2000] 2 AC 59, 74D-F (UK House of Lords, 2000) (Lord Slynn), 113F-G (Lord Millett); CES v. Superclinics (Australia) Pty Ltd (1995) 38 NSWLR 47, (NSW Supreme Court, 1995) 79B-D (Kirby ACJ); Emeh v. Kensington and Chelsea and Westminster Area Health Authority [1985] 1 QB 1012, 1019E-F (Walle LJ), 1024G-1025A (Slade LJ), 1027D-E (Purchas LJ); [1984] 3 All ER 1044 (CA). Contra: CES v Superclinics (Australia) Pty Ltd (1995) 38 NSWLR 47, (NSW Supreme Court, 1995) 84G-85A (Priestley JA).

${ }^{79}$ Cattanach v. Melchior, (2003) 199 ALR 131; [2003] HCA 38 (High Court of Australia, 2003), [220][222] (Hayne J), [301] (Callinan J); Melchior v. Cattanach [2000] QSC 285, (Queensland Supreme Court, 2001) [57] (Holmes J); (2001) Aust Torts Reports 9[81-597; McFarlane v. Tayside Health Board [1999] 4 All ER 961; [2000] 2 AC 59 (UK House of Lords, 2000), 81D-F (Lord Steyn), 113A-B (Lord Millett); Kealey v Berezowski (1996) 136 DLR (4th) 708, 740g-741b; CES v Superclinics (Australia) Pty Ltd (1995) 38 NSWLR 47, (NSW Supreme Court, 1995) 79B-D (Kirby ACJ); Emeh v. Kensington and Chelsea and Westminster Area Health Authority [1985] 1 QB 1012, 1019E-F (Waller LJ), 1024G-H (Slade LJ); [1984] 3 All ER 1044 (CA); SEYMOUR, supra note 5, at 80-81. Contra: CES v Superclinics (Australia) Pty Ltd (1995) 38 NSWLR 47, (NSW Supreme Court, 1995) 87D (Meagher JA).
} 


\section{Pure or consequential economic loss?}

If unwanted pregnancy is not physical damage, then pregnancy costs of a financial nature, and upbringing costs, are all pure economic loss (because consequent upon a condition-unwanted pregnancy - that is not physical damage) and recovery on normal principles will be harder to establish. ${ }^{80}$

It is submitted that 'physical damage' should be taken to include any substantial invasion of bodily interests. Bodily autonomy-the right to decide what happens in and to one's body-is a legally protected interest. ${ }^{81}$ Unwanted pregnancy substantially invades this bodily interest by introducing profound bodily changes to which one does not consent. ${ }^{82}$ Unwanted pregnancy therefore is physical damage, even though pregnancy is in some sense a 'natural' phenomenon. ${ }^{83}$ Thus, Kirby $\mathbf{J}$ in Cattanach held wrongful birth involves 'direct [physical] injury to the parents, certainly to the mother who suffered profound and unwanted physical events (pregnancy and child-birth) involving her person', so that '[a]ny [resulting] economic loss was not pure, but consequential' ${ }^{84}$ It would follow that any part of a wrongful birth claim brought (only) by the mother is a claim for consequential loss; while any part brought (only) by the father is, it seems, a claim for pure economic loss, since the loss is caused by physical damage to a third party (the mother).

What if part of a claim-generally the component for upbringing costs-is brought jointly by both parents? Judges in McFarlane ${ }^{85}$ and Cattanach $^{86}$ held a joint claim is for pure economic loss, since the father is part of the claim and suffers no physical injury: "From his point of view, how could the claim be

\footnotetext{
${ }^{80}$ See: Perre v. Apand Pty Ltd (1999) 198 CLR 180; (1999) 164 ALR 606; [1999] HCA 36 (High Court of Australia, 1999).

${ }_{81}$ Schloendorff v. Society of New York Hospital (1914) 211 NY 125; (1914) 105 NE 92; Health \& Community Services (NT), Department of v. J W B \& S M B (Marion's case) (1992) 175 CLR 218; (1992) 106 ALR 385, (High Court of Ausralia, 1992) 392 (Mason CJ, Dawson, Toohey and Gaudron JJ), 452 (McHugh J).

${ }^{82}$ Parkinson v. St James and Seacroft University Hospital NHS Trust [2001] EWCA Civ 530; [2001] 3 All ER 97 (Supreme Court of Judicature, Civil Division, Court of Appeal, 2001), Hale LJ [56]-[75]; EILEEN MCDONAGH, BREAKING THE ABortion DEADloCK: From CHOICE TO CONSENT , 69-78 \& $84-$ $91(1996)$

${ }^{83}$ McFarlane v Tayside Health Board [1999] 4 All ER 961; [2000] 2 AC 59, (UK House of Lords, 2000) 74B-C (Lord Slynn), 81F-G (Lord Steyn), 86F-H (Lord Hope), 102G-H (Lord Clyde), 107F-G (Lord Millett); Melchior v Cattanach [2001] QCA 246, (Queensland Court of Appeal [77] (Davies JA).

${ }^{84}$ Cattanach v. Melchior, (2003) 199 ALR 131; [2003] HCA 38 (High Court of Australia, 2003), [148] (Kirby J). See also: [193] (Hayne J); CES v. Superclinics (Australia) Pty Ltd (1995) 38 NSWLR 47, (NSW Supreme Court, 1995) 72E-F (Kirby ACJ); Walkin v South Manchester Health Authority [1995] 4 All ER 132; [1995] 1 WLR 1543, 1552F (Auld LJ), 1553B (Roch LJ), 1555G-H (Neill LJ) (CA).

${ }_{85}$ McFarlane v. Tayside Health Board [1999] 4 All ER 961; [2000] 2 AC 59 (UK House of Lords, 2000), 79E-F (Lord Steyn), 89D \& 96H-97A (Lord Hope); but cf 83H-84A (Lord Steyn) and 108H109A (Lord Millett) (both noting the invasion of the mother's bodily interests). See also: Allen v. Bloomsbury Health Authority [1993] 1 All ER 651, 658e (Brooke J) (obiter); (1992) 13 BMLR 47 (QBD).

86 Cattanach v. Melchior, (2003) 199 ALR 131; [2003] HCA 38 (High Court of Australia, 2003), [9] \& [19] (Gleeson CJ), [67] (McHugh and Gummow JJ), [302] (Callinan J), Heydon J not deciding.
} 
anything other than a claim for pure economic loss?" ${ }^{87}$ Yet equally, from the mother's point of view, how could the claim be anything other than a claim for consequential loss? It is not clear, and seems chauvinistic to hold, that the father's view should automatically take priority. Further, as Kirby J noted, the requirement that plaintiffs suffer physical damage in order to recover in negligence stems from a concern to avoid indeterminate liability; and, so long as at least one plaintiff suffers physical damage, that concern is met. ${ }^{88}$ Accordingly, a joint claim should be seen as one for consequential loss.

In short: since unwanted pregnancy is physical damage, the doctor, on normal principles, is liable to the mother, or to mother and father jointly, for pregnancy and upbringing costs.

\section{$4 \quad$ Pure economic loss and wrongful birth}

The requirements for recovery of pure economic loss are described in Perre. ${ }^{89}$ These requirements must be met if, contra the above, unwanted pregnancy is not physical damage, or in any case where the father claims alone.

Separate judgments in Perre leave no single ratio, but the main factors identified as creating a duty of care were: ${ }^{90}$ known reliance ${ }^{91}$ vulnerability; ${ }^{92}$ control $;{ }^{93}$ knowledge of the risk and its magnitude $;{ }^{94}$ an ascertainable class of plaintiffs $;{ }^{95}$ non-interference with existing law $;{ }^{96}$ and non-interference with legitimate commercial interests. ${ }^{97}$ The point of identifying these factors is to avoid the imposi-

Cattanach v. Melchior, (2003) 199 ALR 131; [2003] HCA 38 (High Court of Australia, 2003), [19] (Gleeson CJ) (emphasis added).

88 Cattanach v. Melchior, (2003) 199 ALR 131; [2003] HCA 38 (High Court of Australia, 2003), [149] Kirby J.

${ }_{89}$ Perre v. Apand Pty Ltd (1999) 198 CLR 180; (1999) 164 ALR 606; [1999] HCA 36 (High Court of Australia, 1999).

${ }_{90}$ See also: Melchior v. Cattanach [2000] QSC 285, (Queensland Supreme Court, 2000) Holmes J [61][62]; (2001) Aust Torts Reports 9I81-597; Melchior v Cattanach [2001] QCA 246, (Queensland Court of Appeal, 2001) [44]-[45] (McMurdo P), [98] (Davies JA). But cf the different approach favoured in: Perre v Apand Pty Ltd (1999) 198 CLR 180; (1999) 164 ALR 606; [1999] HCA 36, (High Court of Australia, 1999) [259]-[273] (Kirby J); Caparo Industries Plc v. Dickman [1990] 2 AC 605, (Eng. Court of Appeal, 1990) 617-618; Cattanach v. Melchior, (2003) 199 ALR 131; [2003] HCA 38 (High Court of Australia, 2003), [121]-[122] (Kirby J).

91 Perre v. Apand Pty Ltd (1999) 198 CLR 180; (1999) 164 ALR 606; [1999] HCA 36, (High Court of Australia, 1999) [10] (Gleeson CJ), [30] (Gaudron J), [124]-[126] (McHugh J).

92 Perre v. Apand Pty Ltd (1999) 198 CLR 180; (1999) 164 ALR 606; [1999] HCA 36, (High Court of Australia, 1999) [11] (Gleeson CJ), [105] (McHugh J).

${ }_{93}$ Perre v. Apand Pty Ltd (1999) 198 CLR 180; (1999) 164 ALR 606; [1999] HCA 36, (High Court of Austrakia, 1999, [15] (Gleeson CJ), [42] (Gaudron J), [50] (McHugh J), [215]-[216] (Gummow J).

Perre v. Apand Pty Ltd (1999) 198 CLR 180; (1999) 164 ALR 606; [1999] HCA 36, (High Court of Austrakia, 1999, [50] \& [105] (McHugh J), [205] (Gummow J).

${ }^{95}$ Perre v. Apand Pty Ltd (1999) 198 CLR 180; (1999) 164 ALR 606; [1999] HCA 36, (High Court of Austrakia, 1999, [10] (Gleeson CJ), [50] (McHugh J), [335]-[337] \& [341]-[342] (Hayne J).

${ }_{96}$ Perre v. Apand Pty Ltd (1999) 198 CLR 180; (1999) 164 ALR 606; [1999] HCA 36, (High Court of Austrakia, 1999, [197] (Gummow J).

${ }_{97}$ Perre v. Apand Pty Ltd (1999) 198 CLR 180; (1999) 164 ALR 606; [1999] HCA 36, (High Court of Austrakia, 1999,[50] \& [105] (McHugh J), [211] (Gummow J), [346] (Hayne J). 
tion of liability "in an indeterminate amount for an indeterminate time to an indeterminate class". 98

Typically in wrongful birth, the doctor knows the parents will rely on his or her advice or expertise. The parents are vulnerable (unable to protect their own interests) because they lack specialist medical knowledge and must rely entirely on the doctor to provide such knowledge (and thereby to protect their interests); it is unrealistic to expect them to protect their interests by negotiating a contract under which the doctor or hospital will pay for upbringing costs. ${ }^{99}$ Similarly, the doctor is in control, since his or her conduct will effectively determine whether the parents' interests (for example, in avoiding childbirth) will be protected or infringed. The doctor typically knows of the risk of pregnancy and its magnitude (that it will cause substantial costs, especially if the child turns out disabled). The parents are an ascertainable class known to the doctor: they are at particular risk of damage from the doctor's conduct, since only they will have to bear, whether jointly or severally, the costs of any resulting child (or rather, they and the child will bear those costs: the costs of caring for the child are gratuitous care costs and thus are treated as also incurred by the child himself ${ }^{100}$ ). Imposing a duty of care does not interfere with existing law (since no well-developed laws yet apply to the birth torts) or with legitimate commercial interests (since imposing the duty merely holds the doctor to the standard of care already expected in law and society, and there is no legitimate interest in breaching that standard).

Although these factors are met-and thus although liability for wrongful birth would appear to be determinate-Gleeson CJ in Cattanach held that liability for upbringing costs would be indeterminate. His concerns: (1) 'Parents might go through their lives making financial and other arrangements...to accommodate the needs or reasonable requirements of their children'; it is not clear when such arrangements would count as economic loss. ${ }^{101}$ (2) It is not clear when liability would end: children are often dependent on their parents past age 18 , so liability could in principle extend to weddings, tertiary education, and so on (albeit that these were not part of the claim in Cattanach). ${ }^{102}$ (3) If upbringing costs are recoverable, damages for 'adverse effects on career prospects' must be too-and

\footnotetext{
98 Bryan v. Maloney (1995) 182 CLR 609, (High Court of Australia, 1995) 618 (Mason CJ, Deane and Gaudron JJ), quoting Ultramares Corporation v. Touche 174 NE 441 (1931), 444 (Cardozo CJ). Both quoted in Perre v. Apand Pty Ltd (1999) 198 CLR 180; (1999) 164 ALR 606; [1999] HCA 36, (High Court of Austrakia, 1999, [32] (Gleeson CJ), [106] (McHugh J), [243] (Kirby J), [329] (Hayne J), [393] (Callinan J).

${ }_{99}$ Cf Perre v. Apand Pty Ltd (1999) 198 CLR 180; (1999) 164 ALR 606; [1999] HCA 36, (High Court of Austrakia, $1999,[120] \&$ [123] (McHugh J) (plaintiff's inability to protect itself in contract may be a reason to impose a duty of care).

${ }^{100}$ See: Cattanach v. Melchior, (2003) 199 ALR 131; [2003] HCA 38 (High Court of Australia, 2003), , [48] (Gummow and McHugh JJ), [276] (Callinan J); Griffiths v. Kerkemeyer (1977) 139 CLR 161; (1977) 15 ALR 387 (High Court of Australia, 1977).

${ }^{101}$ Cattanach v. Melchior, (2003) 199 ALR 131; [2003] HCA 38, (High Court of Australia, 2003), [33] (Gleeson CJ).

${ }^{102}$ Cattanach v. Melchior, (2003) 199 ALR 131; [2003] HCA 38 (High Court of Australia, 2003), , [20] \& [32] (Gleeson CJ).
} 
these 'might far exceed the costs of raising and maintaining a child' ${ }^{103}$ (4) Upbringing costs would have to be discounted since the child may provide financial assistance later in life. ${ }^{104}$

Ground (1), however, would equally have denied recovery in Perre. There, the defendant caused the plaintiff to be prohibited from exporting potatoes for five years. ${ }^{105}$ During this time the plaintiffs might equally have made 'financial and other arrangements' to accommodate the prohibition. When would this count as economic loss? A difficult question, perhaps-but no Perre judge considered this a reason to deny recovery. Moreover, the question has a clear answer in wrongful birth: upbringing costs, it can be held, cover actual or likely expenditure on goods or services procured for the child's benefit; they do not cover arrangements designed to generate the funds used to procure those goods and services. Concerning (2), liability would end when the child, on the facts, 'might [reasonably] be expected to be economically self-reliant'. ${ }^{106}$ Weddings and tertiary education could be included ${ }^{107}$ if these were prior to reasonable selfreliance and were reasonable rather than extravagant expenses. ${ }^{108}$ Concerning (3), a claim for loss of earnings (as part of a larger claim for upbringing costs) would be treated straightforwardly as any other claim for loss of earnings. Concerning (4), evidence of likely financial assistance could indeed produce a discount. ${ }^{109}$ Nothing in (1)-(4) shows liability for upbringing costs would be to or for an indeterminate amount, time or class.

A further worry about indeterminate liability is this: ${ }^{110}$ through the new child's birth, siblings may receive less pocket money and presents, while relatives babysitting the child may lose income from more profitable activities. Could they sue for pure economic loss? It seems not. ${ }^{111}$ Other parties might suffer just as much loss: toy stores, video stores, clothes stores and restaurants, since the parents have less money to spend on luxuries; the mother's employer, who must find a replacement during maternity leave; the parents' friends, who must buy more meals because the parents do not treat them to dinner so often; and so on.

\footnotetext{
103 Cattanach v. Melchior, (2003) 199 ALR 131; [2003] HCA 38 (High Court of Australia, 2003), , [32] (Gleeson CJ).

Cattanach v. Melchior, (2003) 199 ALR 131; [2003] HCA 38 (High Court of Australia, 2003),

[34] (Gleeson CJ). Indeterminacy 'does not mean magnitude': [32] (Gleeson CJ). Cf [306]-[311] \& [393] (Heydon J) - ) (similar concerns, but apparently relating to magnitude.).

105 Perre v. Apand Pty Ltd (1999) 198 CLR 180; (1999) 164 ALR 606; [1999] HCA 36 (High Court of Australia, 1999), [2] (Gleeson CJ), [59] (McHugh J).

${ }^{106}$ Cattanach v. Melchior, (2003) 199 ALR 131; [2003] HCA 38 (High Court of Australia, 2003), [138] (Kirby J).

${ }^{107}$ Cattanach v. Melchior, (2003) 199 ALR 131; [2003] HCA 38 (High Court of Australia, 2003), [282]

${ }^{\text {(C9 Callinan J). }}$ Cattanach v. Melchior, (2003) 199 ALR 131; [2003] HCA 38 (High Court of Australia, 2003), | [173]-[175] (Kirby J).

${ }_{10}$ Cattanach v. Melchior, (2003) 199 ALR 131; [2003] HCA 38, (High Court of Australia, 2003), [9] (Gleeson CJ), [310] (Heydon J).

${ }_{111}$ Cattanach v. Melchior, (2003) 199 ALR 131; [2003] HCA 38 (High Court of Australia, 2003), [151] (Kirby J).
} 
Such losses are reasonably foreseeable, but the members of the class are in practice impossible to determine. So once the zone of liability is extended beyond the parents (or rather, parents and child-a non-arbitrary class at particular risk from the doctor's conduct), it becomes indeterminate and must be disallowed. $^{112}$

Thus, the parents and child—but only the parents and child—satisfy the Perre requirements. Hence even if financial pregnancy and upbringing costs are pure economic loss, doctors in typical wrongful birth cases have a duty to prevent that loss. So, on normal principles, doctors in such cases will be liable to the plaintiffs-mother, father, or both jointly-for financial pregnancy and upbringing costs. ${ }^{113}$ A claim for pure economic loss cannot, of course, include damages for pain and suffering.

\section{$5 \quad$ Offsetting benefits and harms}

On normal principles, should the net value of emotional benefits brought to the parents by the child be estimated in financial terms and offset against the damages (if any) for pregnancy and upbringing costs? The Cattanach majority held not. McHugh, Gummow and Kirby $\mathbf{J J}^{114}$ noted Dixon J's statement in Zoanetti: 'when one of two separate interests is benefited in consequence of a wrongful act, the benefit cannot be set off against an injury to the other.'115 McHugh and Gummow JJ continued:

The coal miner, forced to retire because of injury, does not get less damages for loss of earning capacity [or pain and suffering] because he is now free to sit in the sun each day reading his favourite newspaper. Likewise, the award of damages to the parents for their future financial expenditure [or pain and suffering] is not to be reduced by the enjoyment that they will or may obtain from the birth of the child. ${ }^{11}$

The exception would be damages for loss of enjoyment of life: these could, if claimed, be set off against emotional benefits, since the same interest is in-

\footnotetext{
112 The spectre of siblings claiming for loss of enjoyment of life because they must now spend less time with parents- Cattanach v. Melchior, (2003) 199 ALR 131; [2003] HCA 38 (High Court of Australia, 2003), [310] (Heydon J) -is legally absurd, since there is no general duty to avoid emotional distress (short of psychiatric injury) to others: Tame v. State of New South Wales; Annetts v. Australian Stations Pty Ltd (2002) 191 ALR 449; [2002] HCA 35,(High Court of Australia, 2002) [7] (Gleeson CJ), [44] (Gaudron J), [193] (Gummow and Kirby JJ), [243] (Hayne J); Frost v. Chief Constable of South Yorkshire Police [1999] 2 AC 455, (Eng. Court of Appeal) 469 (Lord Goff of Chieveley).

${ }_{113}$ On whether the doctor would be liable to the child for upbringing costs, see: below Part II, B.2

114 Cattanach v. Melchior, (2003) 199 ALR 131; [2003] HCA 38 (High Court of Australia, 2003), [87] (McHugh and Gummow JJ), [173] (Kirby J).

115 Public Trustee v Zoanetti (1945) 70 CLR 266, (High Court of Australia, 1945) 278 (Dixon CJ).

116 Cattanach v. Melchior, (2003) 199 ALR 131; [2003] HCA 38 (High Court of Australia, 2003), [90] (McHugh and Gummow JJ). See also: McFarlane v. Tayside Health Board [1999] 4 All ER 961; [2000] 2 AC 59, (UK House of Lords, 2000) 103A-C (Lord Clyde); Melchior v. Cattanach [2001] QCA 246, (Queensland Court of Appeal, 2001) [56] (McMurdo P), [88] (Davies JA).
} 
volved. ${ }^{117}$ Kirby ${ }^{118}$ and Callinan ${ }^{119} \mathrm{JJ}$ reasoned similarly. Gleeson CJ, however, rejected the miner example as circular:

[The miner's] loss of earning capacity, a recognised head of damages, is not mitigated by his enforced leisure. [In wrongful birth], however, the question is whether human reproduction and the creation of a parent-child relationship is actionable damage. ${ }^{120}$

In other words: to apply the Zoanetti rule, one must already assume that the parent-child relationship-or, more accurately, the financial costs flowing from $\mathrm{it}^{121}$ —are a recognised head of damages; yet to make that assumption is circular, since the very question at stake is whether those costs should be recognised as a head of damages.

This charge of circularity is misplaced. The miner example shows that, on normal principles, damages for pain, suffering and economic loss are not reduced for any emotional benefits brought by the negligence. To apply this to wrongful birth, one assumes - what is taken to be shown on other grounds - that damages for pregnancy and upbringing costs are recoverable on normal principles; one then concludes that these damages are not to be reduced for any emotional benefits brought by the child. Hence, what the example assumes is not that upbringing costs are ultimately recoverable-that really would be circular-but merely that they are recoverable on normal principles. This is not circular. So the miner example does show there should be no offset for emotional benefits.

Of course, the birth of the child may also bring the parents financial benefits, such as statutory welfare benefits. ${ }^{122}$ On normal principles, financial benefits caused by the negligence are offset against financial costs. There is, however, no offset for gifts or insurance payouts, ${ }^{123}$ and in the case of statutory benefits an offset will depend on the intention of the legislation conferring the benefit. ${ }^{124}$ Thus, a reduction in pregnancy and upbringing costs for statutory benefits may be appropriate; but examining the relevant legislation is beyond the scope of this article.

\footnotetext{
${ }^{117}$ Cattanach v. Melchior, (2003) 199 ALR 131; [2003] HCA 38 (High Court of Australia, 2003), [90]

(McHugh and Gummow JJ).
${ }_{118}$ Cattanach v. Melchior, (2003) 199 ALR 131; [2003] HCA 38 (High Court of Australia, 2003), [173][175] (Kirby J), citing Public Trustee v. Zoanetti (1945) 70 CLR 266, (High Court of Australia, 1945) 278 (Dixon CJ) and Sharman v Evans (1977) 138 CLR 563, 578; (1977) 13 ALR 57 (High Court of Australia, 1977).

${ }^{119}$ Cattanach v. Melchior, (2003) 199 ALR 131; [2003] HCA 38 (High Court of Australia, 2003), [297]-[298] (Callinan J).

${ }_{120}$ Cattanach v. Melchior, (2003) 199 ALR 131; [2003] HCA 38 (High Court of Australia, 2003), [37] (Gleeson CJ) (emphasis added).

121 Cattanach v. Melchior, (2003) 199 ALR 131; [2003] HCA 38 (High Court of Australia, 2003), [67][68] (McHugh and Gummow JJ), [148] (Kirby J).

${ }_{122}$ See, for example, the Taxation Laws Amendment (Baby Bonus) Act 2002 (Cth).

${ }_{123}$ National Insurance Co of New Zealand v. Espagne (1961) 105 CLR 569, 573 (Dixon CJ); [1961] ALR 627 (High Court of Australia, 1961).

${ }_{124}$ National Insurance Co of New Zealand v. Espagne (1961) 105 CLR 569; [1961] ALR 627 (High Court of Australia, 1961); Manser v. Spry (1994) 181 CLR 428; (1994) 124 ALR 539, 543-5 (Mason CJ, Brennan, Dawson, Toohey and McHugh JJ) (High Court of Australia, 1994).
} 
On normal principles, then, the doctor in wrongful birth will be liable for pregnancy costs and upbringing costs (though with no damages for pain and suffering if the claim is for pure economic loss); and there should be no offset between pregnancy and upbringing costs on the one hand, and emotional benefits on the other (though there should perhaps be an offset for statutory benefits). In short, ordinary principles permit—indeed require—full recovery with no set-off.

\section{Are There Sound Policy Arguments against Recovery?}

Full recovery with no set-off is often rejected for policy reasons. The main policy arguments will be considered by subject-matter: (1) the value of the child and family relationships; (2) justice and proportionality; (3) miscellaneous. It will be asked, of each argument, what damages ${ }^{125}$ would result if the argument were accepted; but it will be shown that each should be rejected.

1 The value of the child and family relationships

(a) The 'blessing' argument

A child's existence has been held a 'blessing', a benefit to the parents, who thus could not have suffered any loss or damage (at least not any overall loss or damage), and so have no cause of action in negligence. That is, although a child brings harms as well as benefits, 'the benefits must be regarded as outweighing any loss. ${ }^{126}$

This argument, originating in the US, ${ }^{127}$ has been rejected ${ }^{128}$ more than accepted. ${ }^{129}$ Four problems with it emerge. First, the argument contradicts normal principles by assuming that emotional benefits can be offset against-and so 'outweigh'-financial and other costs. As argued, normal principles permit no such offset.

\footnotetext{
${ }^{125}$ See: above, Part, II, A.2.

126 McFarlane v. Tayside Health Board [1999] 4 All ER 961; [2000] 2 AC 59, (UK House of Lords, 2000) $111 \mathrm{~F}$ (Lord Millett).

${ }_{127}$ Public Health Trust v. Brown 388 So.2d 1084 (1980), 1085-6; Cockrum v. Baumgartner 447 NE 2d 385 (1983) (Illinois State Court, 1983).

${ }^{128}$ Cattanach v. Melchior, (2003) 199 ALR 131; [2003] HCA 38, (High Court of Australia, 2003), [79] (McHugh and Gummow JJ), [148] (Kirby J), [196] (Hayne J), [350] (Heydon J); Melchior v. Cattanach [2001] QCA 246, (Queensland Court of Appeal, 2001) [51] (McMurdo P), [81]-[82] (Davies JA); Melchior v. Cattanach [2000] QSC 285, (Queensland Supreme Court, 2000) [51] (Holmes J); (2001) Aust Torts Reports II81-597; McFarlane v. Tayside Health Board [1999] 4 All ER 961; [2000] 2 AC 59, (UK House of Lords, 2000) 75B (Lord Slynn), 100D-E (Lord Clyde); CES v. Superclinics (Australia) Pty Ltd (1995) 38 NSWLR 47, (NSW Supreme Court, 1995) 73G-74D (Kirby ACJ); Thake v Maurice [1986] 1 QB 644, 666G (Peter Pain J); [1986] 1 All ER 497 (CA) (Court of Appeal, 1986).

129 McFarlane v Tayside Health Board [1999] 4 All ER 961; [2000] 2 AC 59, (UK House of Lords, 2000) 113H-114B (Lord Millett); CES v Superclinics (Australia) Pty Ltd (1995) 38 NSWLR 47, (NSW Supreme Court, 1995) 87A-B (Meagher JA); Udale v Bloomsbury Health Authority [1983] All ER 522; [1983] 1 WLR 1098 (QBD), 1109F (Jupp J); see also: Kealey v Berezowski (1996) 136 DLR (4th) 708, 732a-b.
} 
Second, the argument entails there can be no recovery for wrongful birth: as there is no damage overall — as any loss is 'outweighed' by the emotional benefits of raising a child-therefore no damages would be recoverable. ${ }^{130}$ This seems unjust: prima facie, it would be more just to award some damages to the plaintiffs rather than no damages at all.

Third, measures to avoid childbirth—abstinence, abortion, the 'rhythm' method, contraception, and sterilisation - are used at some time by many heterosexual people precisely because they believe (correctly) that there are circumstances where having an extra child, even a healthy child, would not benefit the parents overall. ${ }^{131}$ If every child were a blessing, the goal of life during one's fertile years would be 'unlimited child bearing, ${ }^{132}$ for each procreation would leave one better off. As this is manifestly absurd-there is more to life than procreation-not every child is a benefit. Also, that particular parents decide to keep the child does not mean they regard it as a blessing: ${ }^{133}$ they may rather feel that, while no child would have been best, keeping the child is better, morally or emotionally, than abortion or adoption.

Fourth, difficulties arise in severe disability. Parents whose relationships and life-plans are dashed because they must constantly care for a severely disabled child have plainly not benefited overall from the child's existence. There would, as with every child, be particular benefits, some joys; but, overall, the parents are worse off: it would be better for the parents if the child had never existed. So, not every child is a blessing.

Proponents of the 'blessing' argument might then reply that only 'normal, healthy' ${ }^{134}$ children are necessarily beneficial to their parents. But this is equally inconsistent with widespread anti-procreative measures, and is discriminatory. ${ }^{135}$ It is discriminatory because many disabled children are more beneficial to their parents than many healthy children; and so to deny all disabled children the privileged status of 'necessarily beneficial' is unjust discrimination-denial of a privilege on the basis of a general characteristic (disability) while ignoring relevant differences between cases.

\footnotetext{
${ }^{130}$ Cattanach v. Melchior, (2003) 199 ALR 131; [2003] HCA 38 (High Court of Australia, 2003), [120] (McHugh and Gummow JJ); Thake v Maurice [1986] 1 QB 644, 667G-668B (Peter Pain J); [1986] 1 All ER 497 (CA); contra: McFarlane v Tayside Health Board [1999] 4 All ER 961; [2000] 2 AC 59, (UK House of Lords, 2000) 114E-115A (Lord Millett).

${ }_{131}$ Cattanach v. Melchior, (2003) 199 ALR 131; [2003] HCA 38 (High Court of Australia, 2003), [79] (McHugh and Gummow JJ), [164]-[165] (Kirby J); CES v. Superclinics (Australia) Pty Ltd (1995) 38 NSWLR 47, (NSW Supreme Court, 1995) 74A-B (Kirby ACJ); Thake v Maurice [1986] 1 QB 644, 666G (Peter Pain J); [1986] 1 All ER 497 (CA) (Court of Appeal, 1986).

${ }_{132}$ Melchior v. Cattanach [2001] QCA 246, (Queensland Court of Appeal, 2001) [82] (Davies JA).

${ }^{133}$ McFarlane v. Tayside Health Board [1999] 4 All ER 961; [2000] 2 AC 59, (UK House of Lords, 2000) $111 \mathrm{C}$ (Lord Millett)

${ }^{134}$ McFarlane v. Tayside Health Board [1999] 4 All ER 961; [2000] 2 AC 59, (UK House of Lords, 2000) 111D \& 114B (Lord Millett)

${ }_{135}$ Cattanach v. Melchior, (2003) 199 ALR 131; [2003] HCA 38 (High Court of Australia, 2003), [78] (McHugh and Gummow JJ), [164] \& [166] (Kirby J); Melchior v Cattanach [2001] QCA 246, [29] (McMurdo P).
} 
(b) Estimation, commodification, denigration

It is said that to determine the plaintiff's overall loss one must estimate in financial terms the net value of emotional benefits the child will provide to the parents, and then offset this amount against the financial losses the parents suffer. ${ }^{136}$ But, it is said, one cannot financially estimate the value of a human relationship. ${ }^{137}$ Even if one could, financially estimating the child's value to the parents is contrary to key legal and moral values because it treats the child as a commodity. ${ }^{138}$ Further, parents, in an attempt to reduce the offset, would be induced to denigrate their child: they would urge, and courts might accept, the 'unedifying proposition ${ }^{, 139}$ that the emotional benefits are very small, that the child is more trouble financially than it is worth emotionally. ${ }^{140}$ Since, therefore, the emotional benefits cannot, or at least should not, be estimated, the plaintiffs cannot show whether or to what extent they have suffered overall loss, and so no recovery—at least of upbringing expenses—-should be permitted. ${ }^{141}$

Like the 'blessing' argument, this argument fails by assuming, against normal principles, that an offset should be made for emotional benefits. The other steps are therefore irrelevant-but also unpersuasive. Financially estimating emotional benefits is hardly impossible given the law's routine estimation of 'nebulous items such as pain and suffering and loss of reputation. ${ }^{142}$ Such estimation does not treat the child as a commodity, but merely treats the benefits as roughly financially estimable in order to determine just compensation. If this unacceptably 'commodifies' the parent-child relationship, then financial estimation of gratuitous care services must likewise 'commodify' the gratuitous carer-cared relationship. Yet damages for gratuitous care are allowed. ${ }^{143}$

The proposition that a child costs more financially than it is worth emotionally is unedifying but irrelevant. The appropriate set-off, if there is to be one, is not between financial costs and emotional benefits, but between financial and non-

\footnotetext{
${ }^{136}$ Cattanach v. Melchior, (2003) 199 ALR 131; [2003] HCA 38 (High Court of Australia, 2003), [257]-[258] (Hayne J); cf [36]-[37] (Gleeson CJ) (also favouring this approach).

Cattanach v. Melchior, (2003) 199 ALR 131; [2003] HCA 38, (High Court of Australia, 2003), [38] (Gleeson CJ), [247] (Hayne J), [356] (Heydon J); McFarlane v. Tayside Health Board [1999] 4 All ER 961; [2000] 2 AC 59, (Eng. Court of Appeal, 1999) 97D (Lord Hope).

${ }_{138}$ Cattanach v. Melchior, (2003) 199 ALR 131; [2003] HCA 38 (High Court of Australia, 2003), [261] (Hayne J), [353] (Heydon J); see also [35] (Gleeson CJ) and Melchior v Cattanach [2001] QCA 246, (Queensland Court of Appeal, 2001)[197] (Thomas JA) (both raising similar concerns).

${ }^{139}$ McFarlane v Tayside Health Board [1999] 4 All ER 961; [2000] 2 AC 59, (Eng. Court of Appeal, 1999) $111 \mathrm{~F}$ (Lord Millett).

Cattanach v. Melchior, (2003) 199 ALR 131; [2003] HCA 38 (High Court of Australia, 2003),[259][260] (Hayne J), [367]-[370] (Heydon J); CES v. Superclinics (Australia) Pty Ltd (1995) 38 NSWLR 47, (NSW Supreme Court, 1995) 87C (Meagher JA); Udale v. Bloomsbury Health Authority [1983] All ER 522; [1983] 1 WLR 1098 (QBD), 1109D-E (Jupp J).

${ }^{141}$ Cattanach v. Melchior, (2003) 199 ALR 131; [2003] HCA 38 (High Court of Australia, 2003), [262] (Hayne J); see also [404]-[405] (Heydon J).

${ }_{142}$ Cattanach v. Melchior, (2003) 199 ALR 131; [2003] HCA 38 (High Court of Australia, 2003), [144] (Kirby J); see also [200] (Hayne J).

${ }^{143}$ Griffiths v. Kerkemeyer (1977) 139 CLR 161; (1977) 15 ALR 387 (High Court of Australia, 1977); Van Gervan v. Fenton (1992) 175 CLR 327; (1992) 109 ALR 283 (High Court of Australia, 1992); Kars v. Kars (1996) 187 CLR 354 (High Court of Australia, 1996); (1996) 141 ALR 37.
} 
financial costs and emotional benefits. Non-financial costs include the pain and suffering of pregnancy, plus substantial emotional costs: loss of reproductive autonomy; ${ }^{144}$ loss or postponement of life-plans and career goals; and the inconvenience - such as tantrums - of bringing up a child. In most cases where a child is not planned, these emotional costs could reasonably be held of themselves to outweigh emotional benefits. ${ }^{145}$ A court worried about denigration could then deliberately overestimate the child's emotional benefits by deeming, whether the child is healthy or disabled, that emotional benefits equal emotional costs ${ }^{146}$ (this may be called the 'overestimation' solution). Since emotional benefits and emotional costs would thus cancel each other out, other categories of loss-pregnancy costs (including pain and suffering) and upbringing costs-would still be fully recoverable with no further set-off. This solution overestimates the child's emotional benefits but still allows the parents to recover the costs resulting from the negligence; hence it is more just than a solution that, by refusing to estimate emotional benefits, leaves the victims of negligence uncompensated. The 'overestimation' solution also eliminates 'commodification' worries, since emotional benefits are compared with emotional costs, not money. Further, any incentive to denigrate the child is removed, since the offset is conclusively deemed and denigration will not reduce it.

Unless this 'overestimation' solution is adopted, 'commodification' arguments entail there must be no recovery for wrongful birth. ${ }^{147}$ The reason is that, if emotional benefits are to be set off against financial costs occurring after birth (as 'commodification' arguments assume), those benefits must also as a matter of consistency be set off against financial costs, pain and suffering occurring before birth: there is no principled reason why there would be an offset against one but not the other. Since the emotional benefits allegedly cannot or should not be estimated, the plaintiffs would be barred from showing whether or to what extent they have suffered overall loss at all (whether before or after birth). Hence they would not be entitled to recover at all: not even for pain, suffering, or extra disability costs, ${ }^{148}$ since these items (barring an unprincipled and arbitrary exception ${ }^{149}$ ) would equally be subject to set-off against inestimable emotional benefits. Thus, if a set-off is allowed and 'commodification' worries are accepted, the choice is between the 'overestimation' solution and no recovery. 'Overestimation' is more just.

\footnotetext{
144 McFarlane v. Tayside Health Board [1999] 4 All ER 961; [2000] 2 AC 59, (UK House of Lords, 1999) 114F (Lord Millett).

${ }^{145}$ See: Maclean, supra note 8.

${ }^{146}$ See: Thake v. Maurice [1986] 1 QB 644, 667F (Peter Pain J), 682E-G \& 683D (Kerr LJ; Neill and Nourse LJJ agreeing); [1986] 1 All ER 497 (CA); Kealey v. Berezowski (1996) 136 DLR (4th) 708, 738g-739a (Lax J); Parkinson v. St James and Seacroft University Hospital NHS Trust [2001] EWCA Civ 530; [2001] 3 All ER 97, 122g-j \& 123c-d (Hale LJ).

${ }^{147}$ See: McFarlane v Tayside Health Board [1999] 4 All ER 961; [2000] 2 AC 59, (UK House of Lords, 2000) 111F (Lord Millett); Cattanach v. Melchior, (2003) 199 ALR 131; [2003] HCA 38 (High Court of Australia, 2003), [355]-[356] (Heydon J).

${ }^{148}$ McFarlane v. Tayside Health Board [1999] 4 All ER 961; [2000] 2 AC 59 (UK House of Lords, 2000), 114D-E (Lord Millett); contra: Cattanach v. Melchior, (2003) 199 ALR 131; [2003] HCA 38 (High Court of Australia, 2003), [262]-[263] (Hayne J).

${ }^{149}$ See Cattanach v. Melchior (2003) 199 ALR 131; [2003] HCA 38, [165] (Kirby J).
} 
In sum, 'commodification' arguments are irrelevant because normal principles permit no set-off. If set-off were permitted, the 'overestimation' solution should be adopted, which would leave pregnancy and upbringing costs recoverable.

\section{(c) Harm and distress to the child}

Another common argument ${ }^{150}$ claims that recovery of damages, or at any rate upbringing costs, should be disallowed because the child may suffer distress on discovering, through the court's official pronouncement, that they were unplanned; that the parents sued for pregnancy and/or upbringing costs; that the parents believed they would have been better off without the child; that the child was raised with funds supplied by a doctor; or (in some cases, based on the difference between the damages awarded and the sort of upbringing the child knows he actually had) that the parents failed to spend the damages for the child's benefit.

This argument fails on several counts. First, it is not clear how 'the possibility of detriment to a person not party to the action'-the child-could 'prevent recovery of damages'. ${ }^{151}$ That an action distresses the defendant's (or even plaintiff's) spouse, for example, is not a reason to deny compensation.

Second, judicial pronouncements of likely harm lack empirical evidence, ${ }^{152}$ while weaker claims of a mere risk of harm ${ }^{153}$ do not justify outright denial of compensation, since the certain harm to parents in denying compensation may well exceed the merely possible harm to children in granting it.

Third, distress to the child would generally be outweighed by the substantial benefit — security of upbringing — provided by damages. ${ }^{154}$

Fourth, 'there are many harsher truths ${ }^{, 155}$ children may discover than that they were unplanned; the discovery is common and outweighed by subsequent love. ${ }^{156}$ Knowledge that the parents sued will not cause distress if it is explained

\footnotetext{
${ }^{150}$ Cattanach v Melchior (2003) 199 ALR 131; [2003] HCA 38, [372] - [402] (Heydon J); Melchior v Cattanach [2001] QCA 246, [169] (Thomas JA); CES v Superclinics (Australia) Pty Ltd (1995) 38 NSWLR 47, 86B-C (Meagher JA); Udale v Bloomsbury Health Authority [1983] All ER 522; 1 WLR 1098 (QBD), 1109D (Jupp J).

${ }_{151}$ Cattanach v. Melchior, (2003) 199 ALR 131; [2003] HCA 38 (High Court of Australia, 2003), [203] (Hayne J) (original emphasis).

${ }_{152}$ Cattanach v. Melchior, (2003) 199 ALR 131; [2003] HCA 38 (High Court of Australia, 2003), [79] (McHugh and Gummow JJ); see also [145] \& [152] (Kirby J), [203] (Hayne J).

${ }^{153}$ Cattanach v. Melchior, (2003) 199 ALR 131; [2003] HCA 38 (High Court of Australia, 2003), [390] ff (Heydon J).

154 Cattanach v. Melchior, (2003) 199 ALR 131; [2003] HCA 38 (High Court of Australia, 2003), [203] (Hayne J); Melchior v. Cattanach [2001] QCA 246 (Queensland Court of Appeal, 2001), [94] (Davies JA); Emeh v. Kensington and Chelsea and Westminster Area Health Authority [1985] 1 QB 1012, 1021E (Waller LJ); [1984] 3 All ER 1044 (CA) (UK Court of Appeal, 1984); Thake v. Maurice [1986] 1 QB 644, 667C-D (Peter Pain J); [1986] 1 All ER 497 (CA) (UK Court of Appeal, 1986).

${ }^{155}$ Cattanach v. Melchior, (2003) 199 ALR 131; [2003] HCA 38 (High Court of Australia, 2003), , [301] (Callinan J).

${ }^{156}$ Cattanach v. Melchior, (2003) 199 ALR 131; [2003] HCA 38 (High Court of Australia, 2003), [145] (Kirby J); Melchior v. Cattanach [2001] QCA 246 (Queensland Court of Appeal, 2001), [59] (McMurdo P); McFarlane v. Tayside Health Board [1999] 4 All ER 961; [2000] 2 AC 59 (House of Lords, 2000),
} 
that this was merely to avoid certain financial costs and was done for the child's benefit: ${ }^{157}$ 'Because we love you, we wanted to ensure we could afford a good upbringing.' Of course, one cannot completely 'negate the risk of an irrational reaction' from the child, ${ }^{158}$ but then, denying compensation might equally produce irrational reactions from children who become angry that their parents brought them into the world without knowing they could obtain the means to support them.

Fifth, the risk of harm (if there is one) will vary between cases, so respect for privacy and autonomy would require that parents, not courts, be left to decide if suing will harm the child. To hold that the parents' 'conflict between duty and interest'-duty not to harm the child, self-interest in compensation-should be 'removed' because the parents cannot be trusted to resolve it fairly ${ }^{159}$ is paternalistic and inaccurate.

Sixth, if no offset is allowed for emotional benefits, ${ }^{160}$ or if an offset is allowed and the 'overestimation' solution is adopted, then there is no suggestion the parents are emotionally worse off through the child's existence; merely that they are financially worse off (which is obvious and inoffensive). In any case, it is precisely if the court fails to award damages that the parents may be worse off because of the child. An award of damages would itself be a benefit flowing from the child's existence, and would ensure the parents are not worse off.

Seventh, knowledge that upbringing costs came from a doctor would be no more distressing than knowledge that they came from lottery winnings, or a kindly stranger. The funds come from a doctor, but thereupon become the parents', and the child will happily enjoy the benefits that flow from them. If the parents invest the damages imperfectly, the child will enjoy less than the full benefit; ${ }^{161}$ but invariably the child will still benefit substantially ${ }^{162}$-and, as long as this is so, the child is unlikely to be overly distressed about how much more money should have been spent.

Finally, the 'distress' argument, like 'blessing' and 'commodification', entails there must be no recovery for wrongful birth. So long as some damages are recoverable, the child may read the court's judgment and discover he was unplanned and that the parents sued for associated costs-a discovery that can be

75E (Lord Slynn); Thake v. Maurice [1986] 1 QB 644, 667C (Peter Pain J); [1986] 1 All ER 497 (UK Court of Appeal, 1986) (CA).

${ }^{157}$ Cattanach v. Melchior, (2003) 199 ALR 131; [2003] HCA 38 (High Court of Australia, 2003), [145]

(Kirby J).

${ }^{158}$ Cattanach v. Melchior, (2003) 199 ALR 131; [2003] HCA 38 (High Court of Australia, 2003), [399] (Heydon J).

159 Cattanach v. Melchior, (2003) 199 ALR 131; [2003] HCA 38 (High Court of Australia, 2003), [400] (Heydon J)

${ }^{160}$ Melchior v. Cattanach [2001] QCA 246 (Queensland Court of Appeal), [97] (Davies JA).

${ }^{161}$ Cattanach v. Melchior, (2003) 199 ALR 131; [2003] HCA 38 (High Court of Australia, 2003), [401]

(Heydon J).

${ }^{162}$ Cattanach v. Melchior, (2003) 199 ALR 131; [2003] HCA 38 (High Court of Australia, 2003), [176] (Kirby J). 
prevented only by barring recovery completely. ${ }^{163}$ This, however, seems plainly unjust. The assertion (made in an attempt to avoid this injustice) that recovery of pregnancy costs might nevertheless be allowed as 'a not unreasonable compromise ${ }^{164}$ simply ignores the inconsistency between that compromise and the 'distress' argument.

\section{Justice and proportionality}

(a) Intuitions about justice and assumption of responsibility

To some judges, recovery of upbringing costs is intuitively inappropriate. The fact that the doctor would have to pay for food and entertainment is said to 'prompt questions as to the nature of the entire claim'. ${ }^{165}$ Or it is said most people would '[i]nstinctively' think an award of upbringing costs immoral. ${ }^{166}$ Such intuitions, however, are too controversial to justify a departure from normal principles: ${ }^{167}$ 'Intuitive feelings for justice seem a poor substitute for a rule antecedently known, more particularly where all do not have the same intuitions. ${ }^{, 68}$ Equally unconvincing is the claim that ' $[\mathrm{t}] \mathrm{he}$ doctor does not assume responsibility' for upbringing costs. ${ }^{169}$ If this means the doctor does not intentionally assume responsibility, then it is irrelevant, since intention is not an element of negligence; while if it is simply an assertion, based on intuition, that the doctor has no legal responsibility for upbringing costs, then this assumes what is at stake. ${ }^{170}$ In any case, intuition-based arguments can have even less force in Australia, where policy considerations have less prominence. ${ }^{171}$

Any option on damages could be supported by appeal to intuition: one simply asserts the chosen option is 'intuitively correct'. But intuition-based arguments against recovery of upbringing costs are unpersuasive because they merely state a conclusion without justifying it-without identifying, in other words, the features and principles that make an award of upbringing costs inap-

\footnotetext{
${ }^{163}$ Cattanach v. Melchior, (2003) 199 ALR 131; [2003] HCA 38 (High Court of Australia, 2003),, [396] $\&[410]-[411]$ (Heydon J)

${ }_{164}$ Cattanach v. Melchior, (2003) 199 ALR 131; [2003] HCA 38 (High Court of Australia, 2003), [396] (Heydon J).

165 Cattanach v. Melchior, (2003) 199 ALR 131; [2003] HCA 38 (High Court of Australia, 2003), [36] (Gleeson CJ); but cf [2] (Gleeson CJ) (rejecting such appeals to intuition). See also Melchior v. Cattanach [2001] QCA 246 (Queensland Cour of Appeal), [196], [198] (Thomas JA).

${ }_{166}$ McFarlane v. Tayside Health Board [1999] 4 All ER 961; [2000] 2 AC 59, (House of Lords, 2000) 82D (Lord Steyn).

${ }^{167}$ Parkinson v. St James and Seacroft University Hospital NHS Trust [2001] EWCA Civ 530; [2001] 3

All ER 97 (Supreme Court of Judicature, Civil Division, Court of Appeal, 2001), [82] (Hale LJ).

168 National Insurance Co of New Zealand v Espagne (1961) 105 CLR 569, 572 (Dixon CJ); [1961] ALR 627, (High Court of Australia, 1961).

${ }_{169}$ McFarlane v. Tayside Health Board [1999] 4 All ER 961; [2000] 2 AC 59, (Eng. Court of Appeal, 2000) 76 C (Lord Slynn).

${ }^{170}$ Hoyano, supra note 5 at 883-906, 887.

171 Sullivan v. Moody; Thompson v. Connon (2001) 207 CLR 562; (2001) 183 ALR 404, (High Court of Australia, 2001) 415 (Gleeson CJ, Gaudron, McHugh, Hayne and Callinan JJ).
} 
propriate. This unprincipled approach has led, in the UK, to confusion and Clyde).II arbitrariness. $^{172}$

\section{(b) Proportionality and moderation of damages}

In Cattanach, Heydon J warned that 'if the law permits recovery [of upbringing costs] at all, damages will be sought [and awarded] in immoderate amounts which may become....unreasonable.' ${ }^{173}$ 'Rich parents' might seek to recover 'the cost of expensive clothes, toys, pastimes, presents and parties of the type which the planned siblings of the unplanned child had enjoyed or were going to enjoy. ${ }^{174}$ Claims for house extensions, larger family cars, boarding school, upbringing past age 18, and tertiary education—perhaps at Princeton-might likewise produce very substantial damages. ${ }^{175}$ Heydon $\mathrm{J}$ did not see this as 'in itself necessarily an argument against recovery ${ }^{176}$ (why he mentioned it is thus unclear), but others have argued that 'the expense of child rearing would be wholly disproportionate to the doctor's culpability'. ${ }^{177}$ That is, 'the extent of the liability', if upbringing costs were awarded, would be 'disproportionate to...the extent of the negligence. ${ }^{178}$ This argument, if accepted, would justify awarding pregnancy costs without upbringing costs (since pregnancy costs are presumably not 'disproportionate' to culpability). It would preclude recovery of extra disability costs, since these would often exceed the already 'disproportionate' upbringing costs of a normal child. ${ }^{179}$

Despite certain isolated statements, ${ }^{180}$ there is no common law principle that damages must be proportionate to culpability. Particularly where vulnerable people are injured, 'the damages recoverable may [greatly exceed] the tortfeasor's initial culpability'. ${ }^{181}$ In Rogers $v$ Whitaker, ${ }^{182}$ for example, the defen-

\footnotetext{
${ }^{172}$ Hoyano, supra note 5, at 905; Cattanach v. Melchior (2003) 199 ALR 131; [2003] HCA 38 (High Court of Australia, 2003), [163]-[166] (Kirby J). See also: Rees v Darlington Memorial Hospital NHS Trust [2003] UKHL 52 (House of Lords, 2003)

173 Cattanach v. Melchior (2003) 199 ALR 131; [2003] HCA 38 (High Court of Australia, 2003), [393] (Heydon J). See also: McFarlane v. Tayside Health Board [1999] 4 All ER 961; [2000] 2 AC 59 (House of Lords, 2000), 91C-D (Lord Hope), 106A-B (Lord Clyde); Allen v. Bloomsbury Health Authority [1993] 1 All ER 651, 662d-f; (1992) 13 BMLR 47 (QBD) (House of Lords, 1993).

${ }_{174}$ Cattanach v. Melchior (2003) 199 ALR 131; [2003] HCA 38 (High Court of Australia, 2003), [306] (Heydon J).

175 Cattanach v. Melchior (2003) 199 ALR 131; [2003] HCA 38,,(High Court of Australia, 2003) [306][309] (Heydon J).

176 Cattanach v. Melchior (2003) 199 ALR 131; [2003] HCA 38 (High Court of Australia, 2003), [311] (Heydon J).

${ }_{178}$ McFarlane v. Tayside Health Board [1999] 4 All ER 961; [2000] 2 AC 59 (House of Lords, 2000), | 91E (Lord Hope); see also Kealey v. Berezowski (1996) 136 DLR (4th) 708 (Ontario Court, General Division), $741 \mathrm{~b}-\mathrm{c}$.

179 Hoyano, supra note 5, at 891.

180 Caltex Oil (Australia) Pty Ltd v. The Dredge 'Willemstad' (1976) 136 CLR 529 (High Court of Australia, 1976), 551-552 (Gibbs J), 591 (Mason J); Perre v. Apand Pty Ltd (1999) 198 CLR 180; (1999) 164 ALR 606; [1999] HCA 36 (High Court of Australia, 1999), [427] (Callinan J).

181 Cattanach v. Melchior (2003) 199 ALR 131; [2003] HCA 38 (High Court of Australia, 2003), [177] (Kirby J). See also: McFarlane v. Tayside Health Board [1999] 4 All ER 961; [2000] 2 AC 59 (House of Lords, 2000), 109E (Lord Millett); Parkinson v. St James and Seacroft University Hospital NHS Trust [2001] EWCA Civ 530; [2001] 3 All ER 97 (Supreme Court of Judicature, Court of Appeal, Civil
} 
dant's negligence involved failure to disclose a 1 in 14,000 risk of sympathetic opthalmia - a risk many specialists of his kind would also not have disclosed. This barely culpable failure brought damages, in 1992, of $\$ 808,564.38$. Any principle of proportionality-woutd have excluded that amount.- More generally, acceptance in Australia of the 'egg shell skull' rule shows that damages are limited by remoteness, not magnitude; ${ }^{183}$ hence there is no general principle of proportionality. ${ }^{184}$ The spectre of extravagant claims is thus a mere 'useful polemical device', ${ }^{185}$ 'irrelevant to legal principle'. ${ }^{186}$

Deleted: 1977) 138 CLR 563; (1977) 13 ALR 57 (High Court of Australia, 1977), 66 (Gibbs and Stephen JJ).II J).II

hey and McHugh JJ).II

In any case, extravagant claims face difficulties. Plaintiffs are compensated for reasonable, not ideal, requirements. ${ }^{187}$ Thus in Sharman the plaintiff, a quadriplegic, was awarded damages based on future life in hospital rather than (greater) damages for future life at home. The claim for damages based on life at home was unreasonable because life at home would merely increase her happiness, not her health. ${ }^{188}$ Had life at home been expected to increase her health, a cost-benefit analysis would follow: if cost is high and benefits speculative, or if less expenditure would produce almost the same benefit, then that part of the claim is unreasonable. ${ }^{189}$

Adapting this to wrongful birth, it appears upbringing costs would be limited to preservation of the child's health: that which merely increases happiness is unreasonable. However, Cattanach went beyond this, allowing \$200 for an overseas holiday. ${ }^{190}$ Perhaps the reasonable view is that upbringing costs are limited to what is reasonably necessary for the child's reasonable, rather than ideal, welfare. There is a lack of authority here; but a three-step test could apply. First, consider the level of welfare the plaintiffs plan to give the child (as reflected in the claim for damages), and ask whether this level of welfare, by the

Division), 121j-122a (Hale LJ); L Hoyano, Misconceptions about Wrongful Conception 65(6) MLR (2002)883-906, 887.

${ }_{182}$ Rogers v. Whitaker (1992) 175 CLR 479; (1992) 109 ALR 625 (High Court of Australia, 1992). Applied in: Rosenberg v. Percival (2001) 205 CLR 434; (2001) 178 ALR 577 (High Court of Australia, 2001); Naxakis v. Western General Hospital (1999) 197 CLR 269; (1999) 162 ALR 540 (High Court of Australia, 1999); Chappel v Hart (1998) 195 CLR 232; (1998) 156 ALR 517 (High Court of Australia, 1998).

| ${ }^{184}$ See also: Tame v. State of New South Wales; Annetts v. Australian Stations Pty Ltd (2002) 191 ALR 449; [2002] HCA 35 (High Court of Australi, 2002), [192]-[193] (Gummow and Kirby JJ). ${ }^{185}$ Cattanach v. Melchior (2003) 199 ALR 131; [2003] HCA 38 (High Court of Australia, 2003), [210] (Hayne J).

${ }^{186}$ Cattanach v. Melchior (2003) 199 ALR 131; [2003] HCA 38 (High Court of Australia,2003), [154] (Kirby J).

${ }^{187}$ Sharman v. Evans (1977) 138 CLR 563; (1977) 13 ALR 57 (High Court of Australia, 1977), 66 (Gibbs and Stephen JJ), citing Arthur Robinson (Grafton) Pty Ltd v. Carier (1968) 122 CLR 649 at 661; [1968] ALR 257 (High Court of Australia, 1968), 267 (Barwick CJ).

${ }^{188}$ Sharman v. Evans (1977) 138 CLR 563; (1977) 13 ALR 57 (High Court of Australia, 1977), 60 (Barwick CJ), 66 (Gibbs and Stephen JJ).

| ${ }^{192}$ Cattanach v. Melchior (2003) 199 ALR 131; [2003] HCA 38 (High Court of Australia, 2003), [393] (Heydon J). 
standards of modern Australian society, is reasonable rather than ideal or extravagant. To the extent it is ideal or extravagant, the claim is unreasonable. Exclusive private schooling, a Princeton education, a Ferrari on one's $18^{\text {th }}$ birthday, or frequent overseas holidays, would all be excluded on this basis.

Second, ask whether it is reasonably necessary for the plaintiffs to purchase the claimed items in order to achieve the planned level of welfare. The claim is unreasonable to the extent that:

- the plaintiffs could achieve the same level of welfare for the child by buying fewer or less expensive items;

- the claimed items involve substantial cost with little increase in welfare; or

- the child, by the standards of modern Australian society, could reasonably pay for an item himself.

So for example if, on the evidence, state schooling would be virtually as beneficial as private schooling, the cost of the latter would be disallowed. Also, the child in most cases can reasonably pay for tertiary education (via HECS) and at least most of the cost of a wedding (through earnings), so these would not be recoverable.

Third, one would ask whether the claimed upbringing items correspond to the plaintiffs' pre-negligence socio-economic level. To the extent that the claim for damages contemplates a wealthier upbringing than a child born to such plaintiffs would ordinarily expect, the claim is unreasonable, since it would, if accepted, cause the plaintiffs to increase their socio-economic position and so profit from the negligence. ${ }^{191}$ However, no claim is unreasonable if it reflects the minimum necessary to meet the plaintiffs' legal obligations to the child.

In short, it is incorrect to say a restriction to 'moderate' and 'reasonable' damages is "wholly unsound in law.' 192 Claims for damages cannot be extravagant or ideal, and so are confined to what is 'reasonable'-though 'reasonable' may still be substantial.

\section{$3 \quad$ Miscellaneous policy arguments}

\section{(a) Exaggeration of habits and weaknesses}

Following his discovery that '[p]ersonal injury litigation...is not fought in an altruistic way, ${ }^{193}$ Heydon $\mathrm{J}$ feared that if recovery of upbringing costs were

\footnotetext{
194 Cattanach v. Melchior (2003) 199 ALR 131; [2003] HCA 38 (High Court of Australia, 2003), [341] (Heydon J). Heydon J identified many 'temptations' which, as he thought, wrongful birth plaintiffs would be unable to resist (at [338], [334]-[336], [363], [369], [371], [401]). His Honour did not, however, go so far as to suggest (what at any rate seems no less convincing) that wrongful birth plaintiffs, following an award of damages, would be tempted to make their child mysteriously 'disappear' so that the plaintiffs could then enjoy their family habits and pastimes in peace.
} 
permitted, plaintiffs would exaggerate 'family habits' (amounts spent on upbringing) and 'children's weaknesses' (items requiring additional expenditure) in order to secure greater damages. ${ }^{194}$ Exaggeration could not be countered, as in other cases, by 'objective assessments of medical science, ${ }^{, 195}$ and may-to reprise the 'distress' argument—damage the child's 'self-esteem', ${ }^{196}$ if by reading the court's judgment he learns of his weaknesses or fails to live up to exaggerated expectations. ${ }^{197}$

The principle behind this argument appears to be that a given class of legal action-for example, wrongful birth actions-should be disallowed unless the risk of plaintiffs lying in order to secure greater compensation can be countered by 'objective assessments of medical science'. Any such principle, however, is refuted by 'failure to warn' cases. The plaintiff must prove in such cases that he would have acted differently had proper warning been given. ${ }^{198}$ How the plaintiff would have acted depends on his beliefs, desires, temperament: matters generally incapable of objective medical assessment, so that any lies by the plaintiff about how he would have acted cannot be countered by 'objective assessments of medical science'. Yet, while courts are wary of the danger of self-serving testimony, ${ }^{199}$ recovery in 'failure to warn' cases is allowed. As a matter of legal coherence, the same approach-allowing recovery while wary of exaggeration - should apply to wrongful birth. In addition, there are checks on exaggeration in wrongful birth, as courts would rarely accept a child has weaknesses requiring substantial additional expenditure unless a qualified practitioner gave objective evidence to that effect.

As for self-esteem, the child's peers will already have pointed out any weaknesses, ${ }^{200}$ and so the court's judgment tells him nothing new. Similarly, parental expectations are usually expressed, so the child will already know if he has failed to live up to them; whereas if the expectations mentioned in the judgment have not since been mentioned, the child will realise they no longer are, or never were, held. Either way, the judgment will hardly distress the child.

\footnotetext{
195 Cattanach v. Melchior (2003) 199 ALR 131; [2003] HCA 38 (High Court of Australia, 2003), [341] (Heydon J).

196 Cattanach v. Melchior (2003) 199 ALR 131; [2003] HCA 38 (High Court of Australia, 2003), [346] \& [371] (Heydon J).

97 Cattanach v. Melchior (2003) 199 ALR 131; [2003] HCA 38 (High Court of Australia, 2003), [401] (Heydon J).

198 Rogers v. Whitaker (1992) 175 CLR 479; (1992) 109 ALR 625 (High Court of Australia, 1992), 635 (Mason CJ, Brennan, Dawson, Toohey and McHugh JJ; Gaudron J agreeing); Chappel v. Hart (1998) 195 CLR 232; (1998) 156 ALR 517 (High Court of Australia, 1998), 520 (Gaudron J), 527 (McHugh J), 538 (Gummow J), 547-8 (Kirby J), 554-5 (Hayne J); Rosenberg v. Percival (2001) 205 CLR 434; (2001) 178 ALR 577 (High Court of Australia, 2001), 581 (Gleeson CJ), 582-3 (McHugh J), 597 (Gummow J), 618 (Kirby J), 629 (Callinan J)

199 Chappel v. Hart (1998) 195 CLR 232; (1998) 156 ALR 517 (High Court of Australia, 1998), 547-8 (Kirby J); Rosenberg v. Percival (2001) 205 CLR 434; (2001) 178 ALR 577 (High Court of Australia, 2001), 615-618 (Kirby J), 629 \& 632 (Callinan J). See also: Tame v. State of New South Wales; Annetts v. Australian Stations Pty Ltd (2002) 191 ALR 449; [2002] HCA 35 (High Court of Australia, 2002), [194] (Gummow and Kirby JJ).

${ }^{200}$ CES v. Superclinics (Australia) Pty Ltd (1995) 38 NSWLR 47, (NSW Supreme Court, 1995) 86C (Meagher JA).
} 


\section{(b) Coherence with wrongful life claims}

Most common law jurisdictions disallow 'wrongful life' claims, where a disabled child who owes his very existence to medical negligence sues the negligent doctor for the costs of the disability. ${ }^{201}$ Two grounds are often cited: the sanctity of life; and the notion that the child suffers no damage through the negligence, because without the negligence he would not even exist. It has been argued:

[I]t might seem somewhat inconsistent to allow a [wrongful birth] claim by the parents while [a wrongful life claim by] the child, whether healthy or disabled, is rejected. Surely the parents' [wrongful birth] claim is equally repugnant to ideas of the sanctity and value of human life and rests, like that of the child, on a comparison between a situation where a human being exists and one where it does not. ${ }^{202}$

It is incorrect, however, to 'invoke the broad values which few would deny and then glide to the conclusion' that they preclude the plaintiff's claim. ${ }^{203}$ To say the child's life results in compensable damage hardly commits one to saying the child's life is not valuable or sacred. ${ }^{204}$ Moreover, the problem in wrongful life has been to show the plaintiff has suffered damage, given that without the negligence he would not even exist. This problem does not arise in wrongful birth, because without the negligence the plaintiff would still exist. Finally, one can accept the alleged inconsistency and reverse the logic: since wrongful birth claims should be allowed, wrongful life claims should too. ${ }^{205}$ This, it will be argued, is the correct conclusion.

\section{$4 \quad$ Conclusion}

There are no rationally persuasive policy grounds for accepting any option other than that dictated by normal principles: full recovery with no set-off. Cattanach was therefore correctly decided, making denial of wrongful birth

\footnotetext{
${ }^{201}$ See: Part II.A.3 and III.A.4.

${ }^{202}$ F. A. Trindade and Peter Cane, The Law of Torts in Australia 434 (3d ed. 1999). Quoted with approval in McFarlane v. Tayside Health Board [1999] 4 All ER 961; [2000] 2 AC 59, (House of Lords, 2000) 83F-G (Lord Steyn); quoted in Cattanach v. Melchior (2003) 199 ALR 131; [2003] HCA 38, (High Court of Australia, 2003) [408] (Heydon J).

${ }^{204}$ Many who invoke 'sanctity of life' considerations against recovery of damages for wrongful birth would presumably also be opposed to abortion. Yet, ironically, if recovery for wrongful birth were disallowed, greater numbers of potential parents may be led to seek abortion in order to avoid the (unrecoverable) costs of raising a child.

${ }^{205}$ Cf Harriton v. Stephens; Waller v. James; Waller v. Hoolahan [2004] NSWCA 93, (NSW Court of Appeal, 2004) [93], [166] (Mason P) (applying a similar logic).
} 
claims 'the business, if of anyone, of Parliament not the courts'. ${ }^{206}$ The almost hysterical reaction to Cattanach in some quarters is thus based not on sound legal principle but, it would seem, on two factors: general aversion to litigiousness (the suspicion, however misguided, that novel negligence actions are always driven by profit, and that wrongful birth plaintiffs must accordingly view their child as a mere cash fund); and religious dogma (the conviction that motherhood is the God-given or 'natural' state of women, so that children, 'a gift from above', ${ }^{207}$ must be treated at all times as a 'blessing' and never as a basis for complaint or compensation). ${ }^{208}$ Neither factor provides a reason to depart from established legal principle.

\section{WRONGFUL LIFE}

\section{A Definitions and Approaches}

\section{$1 \quad$ Wrongful life defined}

Wrongful life occurs where an unplanned disabled child owes his very existence to medical negligence: had the negligence not occurred, the child would never have been born. The negligence may occur as for wrongful birth: negligent diagnosis or advice concerning sterilisation, pregnancy, disability or contraception; or negligent performance of sterilisation or abortion. ${ }^{209}$ Commonly, a doctor negligently fails to diagnose rubella, where diagnosis would have led to lawful ${ }^{210}$ termination: because the diagnosis is not made, a child is born with severe disabilities caused by the rubella. In other cases the disability is genetic. The common feature is that, had proper diagnosis, advice, sterilisation or abortion been given, the parents-who did not want a child, or at least not a disabled child - would have prevented or terminated the pregnancy, so the disabled child would never have been born. (Wrongful life thus contrasts with more straightforward cases where, but for the negligence, the child would have been born without disability.)

In a wrongful life action, the disabled child sues the negligent doctor in respect of the damage caused by the disability; this would generally include pain, suffering, and 'disability costs' - the extra financial costs attributable to the disability, such as the cost of nursing care (these costs are 'extra' compared to the costs a non-disabled person would incur). The label 'wrongful life' is an entrenched and convenient shorthand, though it also misleads: the notion that a person's life could be wrongful is counterintuitive and renders the plaintiff's claim suspect

\footnotetext{
${ }^{206}$ Cattanach v. Melchior (2003) 199 ALR 131; [2003] HCA 38,(High Court of Australia, 2003) [180] (Kirby J).

| ${ }^{211}$ Edwards v Blomeley [2002] NSWSC 460, [6].
} 


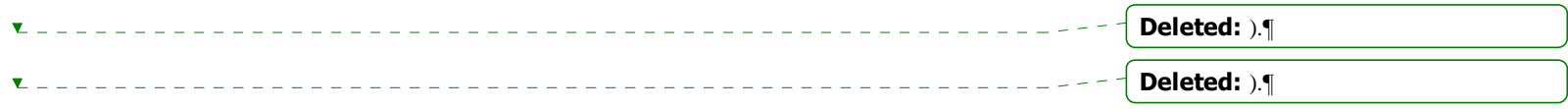

from the outset. What is wrongful is the negligence, not the child's life $;^{211}$ and it is precisely by focusing on the plaintiff's life (as a whole), rather than on negligent causation of physical damage, that courts have been led to misapply ordinary principles and thus deny recovery.

\section{Options for recovery of damages}

The reasonable options appear to be: damages for pain, suffering, and disability costs; disability costs only; or no recovery. It will be argued, however, that in extraordinary cases the child could also recover upbringing costs. Economic losses - disability and upbringing costs - might or might not be offset against economic benefits the child will receive through such sources as employment and statutory welfare benefits.

\section{Existing authorities: UK, US and Canada}

In the UK, wrongful life claims were statute barred shortly after McKay, ${ }^{212}$ leaving this as the leading authority. McKay held that, while the doctor may owe a duty of care to the foetus (or rather, to the born person the foetus will become), no damage in wrongful life cases can be established. To establish damage, one must show the plaintiff is worse off, on account of the negligence, than he would have been without it. Yet, in wrongful life, the plaintiff would not even exist without the negligence. Hence, for 'damage' to be suffered, the plaintiff would have to be worse off existing than not existing. But comparing existence with non-existence (in order to say existence might be worse) is, it was held, impossible; ${ }^{213}$ so no damage can be established. This 'non-existence' argument has been highly influential. McKay also raised worries about children suing their parents for wrongful life, ${ }^{214}$ and the difficulty of specifying 'how gravely deformed' the child must be before a wrongful life claim would be recognised. ${ }^{215}$ The child's claim was thus summarily dismissed.

In the US, three states allow recovery of disability costs only, ${ }^{216}$ while others bar wrongful life actions for essentially the reasons in McKay. ${ }^{217}$ In Canada, wrong-

\footnotetext{
212 McKay v Essex Area Health Authority [1982] 1 QB 1166 (CA), 1177H-1178C (Stephenson LJ). See: Congenital Disabilities (Civil Liability) Act 1976 (UK) s 4(5).

${ }^{214}$ McKay v Essex Area Health Authority [1982] 1 QB 1166 (CA), 1181A-B (Stephenson LJ).

216 California (Curlender v Bio-Sciences Laboratories 106 Cal App 3d 811, 165 Cal Rptr 477 (1980); Turpin v Sortini 643 P 2d 954 (1982)); New Jersey (Procanik v Cillo 478 A 2d 755 (1984)); Washington (Harbeson v Parke-Davis Inc 656 P 2d 483 (1983)). See also: SEYMOUR, supra note 5, at 108-11.

217 Including: Alabama (Elliott v Brown 361 So. 2d 546 (1978)); Arizona (Walker v Mart 790 P.2d 735 (1990)); Colorado (Lininger v Eisenbaum 764 P.2d 1202 (1988)); Delaware (Garrison v Medical Center of Delaware, Inc. 581 A.2d 288 (1989)); Florida (Kush v Lloyd 616 So. 2d 415 (1992)); Georgia (Atlanta Obstetrics \& Gynecology Group v Abelson 398 SE 2d 557 (1990)); Idaho (Blake v Cruz 698 P.2d 315 (1984)); Illinois (Cockrum v Baumgartner 95 Ill. 2d 193, 200-01 (1983); Siemieniec v Lutheran General Hospital 512 NE 2d 691 (1987)); Indiana (Cowe v Forum Group, Inc 575 NE 2d 630 (1991); Kansas (Bruggeman v Schimke 718 P.2d 635 (1986)); Louisiana (Petre v Opelousas General Hospital 517 So 2d 1019 (1987), reversed in part on other grounds, 530 So 2d 1151 (1988)); Massachusetts (Viccaro v.Milunsky 551 N.E.2d 8 (1990)); Michigan (Taylor v Kurapati 600 N.W.2d 670 (1999));
} 
ful life has not been considered at federal level, but lower courts, including one appellate court, have followed McKay. ${ }^{218}$

\section{Existing authorities: Australia}

Deleted: P dissenting).II

).II

A NSW wrongful life claim ${ }^{219}$ was summarily dismissed on the authority of McKay. In a Queensland case where wrongful life was pleaded but not pursued, the judge indicated McKay would have been followed. ${ }^{220}$ In 2002 , three matters were heard together in the NSW Supreme Court. ${ }^{221}$ Studdert J, also following $M c K a y$, held that while the doctor has a duty of care to the foetus (or rather, to the born person the foetus will become), this is merely a duty not to damage or injure; and, since no damage in wrongful life cases can be established, the action must fail. Studdert J also raised policy concerns about contravening the sanctity of human life, harming the self-esteem of the disabled, and allowing children to sue their parents for wrongful life. ${ }^{222}$

Two of the plaintiffs appealed Studdert J's decision. The NSW Court of Appeal dismissed the appeal. ${ }^{223}$ Spigelman CJ held that since a wrongful life plaintiff must assert 'that it would be preferable [for the plaintiff] if she or he had not been born', and since this assertion raises 'highly contestable' ethical issues on which '[t]here is no widely accepted ethical principle', therefore the doctor should owe no duty of care to the child; ${ }^{224}$ for imposing a duty of care 'must reflect values generally, or at least widely, held in the community. ${ }^{, 25}$ Further, 'in order to constitute damage which is legally cognisable...it must be established that non-existence is preferable to life with the disabilities to the child' ${ }^{226}$

Missouri (Wilson v Kuenzi 751 SW 2d 741 (1988)); Nevada (Greco v United States 893 P.2d 345 (1995)); New Hampshire (Smith v Cote 513 A.2d 341 (1986)); New York (Becker v Schwartz 386 N.E. 2d 807 (1978)); North Carolina (Azzolino v Dingfelder 337 S.E.2d 528 (1985)); Ohio (Hester v Dwivedi 733 N.E. 1161 (2000)); Philadelphia (Ellis v Sherman 515 A 2d 1327 (1986)); Texas (Nelson v Kruzen 678 S.W.2d 918 (1984)); West Virginia (James G. v Caserta 332 S.E.2d 872 (1985)); Wisconsin (Dumer v St. Michael's Hospital 233 N.W.2d 372 (1975)); Wyoming (Beardsley v Wierdsma 650 P 2d 288 (1982)). See: Edwards v Blomeley [2002] NSWSC 460, [35]; SEYMOUR, supra note 5, at 107-8.

${ }_{218}$ Arndt v Smith [1994] 8 WWR 568 (British Columbia Supreme Court), overturned on another issue [1995] 2 SCR 539; Jones v Rostig (1999) 44 CCLT (2d) 312 (British Columbia Supreme Court); Lacroix v Dominique [2001] MBCA 122 (Manitoba Court of Appeal); Mickle v Salvation Army Grace Hospital (1988) 166 DLR $\left(4^{\text {th }}\right) 743$ (Ontario General Division). These cases are collected in: Edwards v Blomeley [2002] NSWSC 460, [26]-[32].

219 Bannerman v Mills (1991) ATR 81-079.

| ${ }^{221}$ Edwards v Blomeley [2002] NSWSC 460; Harriton v Stephens [2002] NSWSC 461; Waller v James

[22002] NSWSC 462.
Edwards v Blomeley [2002] NSWSC 460, [119]; Harriton v Stephens [2002] NSWSC 461, [71]; Waller v James [2002] NSWSC 462, [66].

| ${ }^{226}$ Harriton v Stephens; Waller v James; Waller v Hoolahan [2004] NSWCA 93, [43] (Spigelman CJ), original emphasis. 
but as the plaintiffs failed to argue that non-existence would be preferable for them, no damage had been shown. ${ }^{227}$ Ipp JA likewise accepted the 'nonexistence' argument in McKay, holding that since it is 'impossible to use nonexistence as a comparator', ${ }^{228}$ therefore it is impossible to demonstrate either that damage has occurred or what the appropriate measure of damages would be. ${ }^{229}$ Further, wrongful life actions offend the 'weighty' principle of the sanctity of life. ${ }^{230}$

Mason P in dissent held that since wrongful birth and wrongful life both involve 'losses stemming from the creation of life' by medical negligence, they are essentially similar causes of action and it would be 'incoherent' to disallow recovery for wrongful life given that recovery for wrongful birth is allowed. ${ }^{231}$ Further, compensation would be allowed on ordinary principles: wrongful life involves physical damage ${ }^{232}$ (in the form of disability) that is reasonably foreseeable (the plaintiffs 'are persons whom the medical practitioners would have known as likely to come into being and as likely to suffer and have special needs of care if certain steps were not taken ${ }^{, 233}$ ), reasonably preventable (by 'giv[ing] advice and treatment to the mothers that would have prevented the suffering presently endured by the [plaintiffs] ${ }^{234}$ ), and caused by the doctor's conduct (since the doctors 'omitted to give [such] advice and treatment ${ }^{235}$ ). As in Cattanach (where there was no offset for the speculative emotional benefits brought by the child), there is no need for a speculative offset for the putative benefits of existence over non-existence. ${ }^{236}$ Having thus rejected the 'nonexistence' argument as well as other anti-recovery arguments, ${ }^{237}$ Mason P concluded that damages should be awarded.

It will now be argued that normal principles do indeed permit recovery of damages (Section 2); and that the policy arguments against recovery are weak (Section 3).

\footnotetext{
${ }^{227}$ Harriton v Stephens; Waller v James; Waller v Hoolahan [2004] NSWCA 93, [46] (Spigelman CJ). ${ }^{228}$ Harriton v Stephens; Waller v James; Waller v Hoolahan [2004] NSWCA 93, [266] (Ipp JA). ${ }^{229}$ Harriton v Stephens; Waller v James; Waller v Hoolahan [2004] NSWCA 93, [234]-[237], [271], [279], [320]-[321] (Ipp JA). As Spigelman CJ noted (see at [6]), Ipp JA routinely confuses damage (loss or injury) with damages (an amount awarded in compensation for loss or injury); so it is not always clear which one he means. But it emerges (at [279]) that he sees both as problematic. Ipp JA also argued (at [337]) that 'at the present time, when legislatures throughout the country have legislated or have foreshadowed legislation restricting liability for negligence...it would be quite wrong to expand, by judicial fiat, the law of negligence into new areas.' To this Mason P replied (at [164]): 'I know of no legal principle that directs the common law to pause or to go into reverse simply because of an accumulation of miscellaneous statutory overrides.'

${ }^{230}$ Harriton v Stephens; Waller v James; Waller v Hoolahan [2004] NSWCA 93, [303], [348] (Ipp JA).

${ }^{233}$ Harriton v Stephens; Waller v James; Waller v Hoolahan [2004] NSWCA 93, [108] (Mason P).

${ }^{234}$ Harriton v Stephens; Waller v James; Waller v Hoolahan [2004] NSWCA 93, [116] (Mason P).

${ }^{235}$ Harriton v Stephens; Waller v James; Waller v Hoolahan [2004] NSWCA 93, [116] (Mason P)

${ }^{236}$ Harriton v Stephens; Waller v James; Waller v Hoolahan [2004] NSWCA 93, [161]-[162] (Mason P).

${ }^{237}$ Harriton v Stephens; Waller v James; Waller v Hoolahan [2004] NSWCA 93, [121], [124], [135], [139], [141] (Mason P).
} 


\section{B Do Normal Tort Law Principles Support Recovery of Damages?}

\section{Duty and breach of duty: physical damage}

\section{(a) Duty to the foetus}

In wrongful life, the doctor's conduct occurs before the plaintiff's birth. At common law the foetus has no rights until birth, ${ }^{238}$ but doctors have a duty not to damage the foetus, since such damage may cause damage to the born person the foetus will become. A duty of care may thus be owed to a person not yet born. ${ }^{239}$ Similarly, a duty of care may be owed to a person not yet conceived, since present actions may cause damage to the person once conceived and born. ${ }^{240}$ For example, a baby food manufacturer who negligently allows toxins into the food will be liable for injuries caused to babies who ingest the food two years from now, even though some of those babies have not yet been conceived. ${ }^{241}$ In either case the duty is to prevent physical damage to the person who may later be born.

Conversely, if the doctor's conduct cannot cause physical damage to the person who may later be born, there is simply no duty of care (unless on the basis of pure economic loss). A fortiori there would be no breach of duty of care, no causation of damage, and no liability (again, unless on the basis of pure economic loss). So liability in wrongful life depends crucially on whether the doctor's conduct can cause physical damage to the plaintiff.

\section{(b) Physical damage contrasted with damage to the value of} one's life as a whole

McKay and subsequent cases have effectively ignored the issue of physical damage and have instead focused on the plaintiff's life as a whole. They have required the plaintiff to show 'damage' in the sense of his very existence, his life as a whole, being worse off through the negligence than it would otherwise have been (hence the need to show his existence is worse than non-existence, since non-existence is what 'would otherwise have been'). Yet this requirement is misguided, since in no other case is the plaintiff required to prove 'damage' in this sense.

239 Watt v Rama [1972] VR 353; Burton v Islington Health Authority (1993) QB 204; De Martell v Merton \& Sutton Health Authority (1993) QB 204; Edwards v Blomeley [2002] NSWSC 460, [54]. | ${ }^{241}$ X \& Y v Pal, (1991) 23 NSWLR 26, 40 (Clarke JA) (New South Wales Court of Appeal); Waller v James, [2002] NSWSC 462, [17] (New South Wales Supreme Court, 2002).]. 
The Cattanach plaintiffs, for example, were certainly not required to show their lives as a whole were worse off for the birth of their son (and the 'blessing' argument, the claim that their lives were better off, was rejected as irrelevant ${ }^{242}$ ). As a matter of legal coherence, the same definition of 'damage' must apply to wrongful life as applies in other cases. Damage in law is either physical damage or pure economic loss, ${ }^{243}$ and in determining whether either of these has occurred it is not necessary to look to the plaintiff's life as a whole.

Contra McKay, then, the wrongful life plaintiff need not show his life as a whole is worse off as a result of the negligence, and a fortiori need not show his existence is worse than non-existence. He need only show, as with other plaintiffs, ${ }^{244}$ that he suffers reasonably foreseeable, reasonably preventable physical damage caused by the defendant's conduct.

\footnotetext{
${ }^{242}$ See: above, Part II.C.1.(a).

${ }^{243}$ Cattanach v Melchior (2003) 199 ALR 131; [2003] HCA 38, [67] (McHugh and Gummow JJ).

${ }^{246}$ See: Paton v British Pregnancy Advisory Service Trustees \& Another (1979) 1 QB 276 at 279; (1978) 2 All ER 987; C v S [1987] 1 All ER 1230; (1988) 1 QB 135, 140 (Heilbron J); Re F (in utero) (1988) Fam 122, 138 (May LJ); B v Islington Health Authority (1991) 1 QB 638; De Martell v Merton \& Sutton Health Authority (1993) QB 204, 213 (Phillips J); Burton v Islington Health Authority (1993) QB 204, 226 (Dillon LJ); Re MB [1997] 8 Med. L.R. 217; St George's Healthcare NHS Trust v S [1998] 3 All ER 673; [1998] 3 WLR 936 (CA); Attorney-General (Qld); Ex rel Kerr v T (1983) 1 Qd R 396, 400 (Qld SC, Williams J), 406 (Qld CA); (1983) 57 ALJR 285, 287 (High Court, Gibbs CJ); Yunghanns v Candoora No 19 Pty Ltd [1999] VSC 524, [75]-[86]. To illustrate: if a negligently performed amniocentesis causes the foetus temporary pain or deformity but has no effects at or after birth, the person once born could hardly sue for negligence; and this precisely because damage before birth is not damage in law (or in other words, damage in law is always damage to the body, property or finances of a legal person: a legal non-person cannot suffer legally recognised damage).
} 
(c) Can the doctor in wrongful life cause physical damage to the child? In wrongful life, the plaintiff suffers disability. Disability is a recognised head of physical damage. ${ }^{245}$ Thus, the plaintiff suffers physical damage. But since damage in law is always damage to a born person, ${ }^{246}$ the damage is better char

acterised as disability suffered by a born person. If the doctor takes reasonable care (by giving proper advice, diagnosis or treatment), the plaintiff will never be

born, and so damage (to a born person) will never occur. If the doctor fails to take reasonable care (by failing to give proper advice, diagnosis or treatment), physical damage - disability suffered by a born person—will occur. Thus the doctor can allow or prevent physical damage, and so can be held as a matter of common sense and the 'but for' test to have caused that damage (in that his conduct is $a$ cause of it). ${ }^{247}$ Of course, the doctor does not cause the viral or genetic condition that produces disability; ${ }^{248}$ and so his conduct is not the sole or direct biological cause of disability. But the crucial point ${ }^{249}$ is that the doctor's conduct is still $a$ cause of physical damage (in this case, disability suffered by a born person). So the doctor in wrongful life can cause physical damage to the child.

\section{(d) Physical damage and non-existence}

The 'non-existence' argument in McKay claims, contrary to the preceding argument, that the doctor's conduct cannot cause damage, because without the conduct the plaintiff would not even exist. ${ }^{250}$ Although McKay incorrectly focused on the plaintiff's life as a whole, the 'non-existence' argument might equally be thought to show the wrongful life plaintiff suffers no physical damage. ${ }^{251}$

The issue, then, is whether conduct can cause physical damage to the plaintiff in circumstances where the plaintiff, without that conduct, would not even exist.

| ${ }^{248}$ McKay v Essex Area Health Authority [1982] 1 QB 1166 (CA), 1178E-F (Stephenson LJ); Edwards v Blomeley [2002] NSWSC 460, [69]; Harriton v Stephens [2002] NSWSC 461, [25]-[27]; Waller v James [2002] NSWSC 462, [39] \& [43].

249 See: March v E \& MH Stramare Pty Ltd (1991) 171 CLR 506, 511; (1991) 99 ALR 423, 426-7; Medlin v State Government Insurance Commission (1995) 182 CLR 1, 6-7; 127 ALR 180, 183-4; Henville v Walker (2001) 206 CLR 459, 480 \& 490; 182 ALR 37, 50-1 \& 59. See also: Harriton v Stephens; Waller v James; Waller v Hoolahan [2004] NSWCA 93, [121] (Mason P).

250 McKay v Essex Area Health Authority [1982] 1 QB 1166 (CA), 1181D-F (Stephenson LJ), 1189C-D (Ackner LJ), 1191H-1193A (Griffiths LJ); Edwards v Blomeley [2002] NSWSC 460, [72]-[76]; Harriton v Stephens [2002] NSWSC 461, [33]; Waller v James [2002] NSWSC 462, [49]; Harriton v Stephens; Waller v James; Waller v Hoolahan [2004] NSWCA 93, [234]-[237], [271], [279], [320]-[321] (Ipp JA); see also [43], [46] (Spigelman CJ).

${ }^{251}$ Cf Harriton v Stephens; Waller v James; Waller v Hoolahan [2004] NSWCA 93, [42]-[43] (Spigelman CJ) (appearing to endorse this logic). Discussions about non-existence are liable to invoke philosophical speculation rather than established legal principle, and a court wishing to avoid such speculations could simply accept the point (already made: above, Part III.B.1.(c)) that disability is a recognised head of physical damage. 
This certainly seems possible. For example, many wrongful life plaintiffs suffer brain damage. Brain damage is a form of physical damage, since the brain is a physical thing. So many wrongful life plaintiffs suffer physical damage. As argued, the doctor can allow or prevent that damage, and so on ordinary principles causes it. ${ }^{252}$ So the doctor's conduct can cause physical damage even though the plaintiff, without that conduct, would not exist.

More generally, as a matter of common sense (which can be the only guide, since neither authorities nor dictionaries define 'physical damage' in detail), malformed body or brain parts are physical damage even where the alternative is non-existence. For example, suppose rescuer X saves baby Y's life by dragging $Y$ from the path of a speeding train. As a result, part of Y's body or brain-say, a foot that was wedged in the track and had to be forcibly removed-becomes malformed (and thus physically damaged). Here, X's conduct plainly causes physical damage to $\mathrm{Y}$ - the malformed body or brain part-even though, without X's conduct, Y would not exist (and, if that was the only way to save Y, could not exist). Likewise, in wrongful life, the doctor's conduct causes physical damage to the plaintiff - the malformations of brain or body, occurring in a born person, that comprise the disability-even though, without the conduct, the plaintiff would not exist (and, if the disability is genetic, could not exist). In both cases (the $\mathrm{X}$ and $\mathrm{Y}$ case and wrongful life), physical damage is caused even though the alternative is non-existence.

Of course, the rescuer $\mathrm{X}$ could escape liability for the physical damage caused to $\mathrm{Y}$. This, however, is not because $\mathrm{X}$ did not cause physical damage to $\mathrm{Y}$ (as argued, $\mathrm{X}$ did cause such damage); rather because, in negligence, one may permissibly risk or cause lesser damage (such as a malformed foot) in order to prevent greater damage (such as a person's death). ${ }^{253}$ In contrast, since nonexistence (in the sense of never having been born) is not legally recognised damage, one cannot say that the doctor in wrongful life may permissibly risk or cause lesser damage (disability) in order to prevent greater damage (nonexistence). Put another way, the clear social utility of saving a person's life justifies the rescuer's causation of the malformed foot; whereas giving negligent diagnosis, advice or treatment and thereby risking unwanted pregnancy has no clear social utility and hence does not justify the doctor's causation of disability. So the rescuer X, on normal principles, could escape liability in respect of the physical damage he causes; ${ }^{254}$ but the doctor in wrongful life could not necessarily do the same.

\footnotetext{
253 See: Watt v Hertfordshire County Council [1954] 2 All ER 368; [1954] 1 WLR 835; Marshall v | Curry [1933] 3 DLR 260 (Nova Scotia SC); Health \& Community Services (NT), Department of v J W B \& S M B (Marion's case) (1992) 175 CLR 218; (1992) 106 ALR 385, 452 (McHugh J); Krishna v Loustos [2000] NSWCA 272; [2000] ACL Rep 300 NSW 73.

${ }^{255}$ See: SEYMOUR, supra note 5, at 160-164, 176. For the purposes of this paper I assume the common | sense view that we were once foetuses.
} 
It might be objected that the rescue analogy is imperfect for a further reason: had the rescue not occurred, Y would have ceased to exist; whereas in wrongful life, had the doctor's conduct not occurred, the plaintiff never would have existed. This, however, is simply not true of rubella cases, where the plaintiff is already conceived when the negligence occurs and hence would still have existed (as an embryo or foetus, though not as a legal person ${ }^{255}$ ) had the conduct not occurred. Thus at the very least the rubella plaintiff's disabilities would still count as physical damage. Could one then claim that if a failed sterilisation plaintiff suffers the very same sorts of disabilities - but suffers them genetically-then these disabilities do not count as physical damage, since without the conduct the plaintiff really would never have existed? This distinction is untenable: as a matter of common sense, if the disability is the same in each case, it is physical damage in each case (and so for example, if brain damage is physical damage when suffered by a rubella plaintiff, then it is still physical damage when suffered by a failed sterilisation plaintiff). Accordingly, one cannot say it is only rubella plaintiffs who suffer physical damage: other types of wrongful life plaintiff can also suffer physical damage.

Thus, in wrongful life the doctor's conduct can cause physical damage to the child. That damage—disability suffered by a born person—will occur whenever a disabled child (trivially or severely disabled) results from the negligence.

\section{(e) Existence worse than non-existence}

Given the preceding argument, a wrongful life plaintiff seeking to demonstrate damage (in the sense of legally recognised damage) need only show he suffers malformations of brain or body: again, contra McKay, the plaintiff need not show his existence is worse than non-existence.

Nevertheless, it appears the child would also suffer physical damage if his disabilities are so severe that they do restrict him to a life worse than non-existence: a life with so much pain, suffering and indignity, and so little pleasure or meaningful activity, that it genuinely would be better for the child if he did not exist. The damage in such cases is simply the state of (physically) existing. The problem of comparing severely disabled existence with non-existence (so as to say existence might be worse) can be solved by placing the value of non-existence at zero. The value of non-existence must be zero, because non-existence is nothingness, and so has no value-zero value. Fixing non-existence at zero value, one can then ask whether the bad things in the child's life outweigh the good; and, if they do, non-existence would be better.

It may be objected here that non-existence simply cannot be compared to anything else, and that any attempt to do so (for example, by giving it zero value) is misguided. ${ }^{256}$ Yet this objection misfires, since comparisons with non-existence

\footnotetext{
${ }^{256}$ Cf. Harriton v Stephens; Waller v James; Waller v Hoolahan [2004] NSWCA 93, [147] (Mason P) (noting this objection), [266], [271] (Ipp JA) (endorsing essentially this objection).
} 
are both common and necessary in common sense and in law. ${ }^{257}$ For example, one is glad-better off-to exist now than to have been killed five minutes ago. Yet, had one been killed, one would not now exist. So, in saying one is better off alive, one is comparing existence with non-existence and judging that one is better than the other. Similarly, disabled existence has been held a 'gift', ${ }^{258}$ a great benefit, something better than the alternative (which could only be nonexistence). Here, one is again comparing existence with non-existence and judging which is better or worse. Or again: in passive euthanasia, courts have held that, given low enough quality of life, continued life may be worse, or at least no better, than non-existence (death). ${ }^{259}$ In all these cases, comparisons with non-existence - and judgments about which is better or worse-are possible. Logically, then, if one's quality of life were as bad as or worse than in the passive euthanasia cases-as with exceptionally severe disability-then life could be even worse than non-existence.

The objection that it is outside judicial competence to assess whether the plaintiff's existence is worse than non-existence ${ }^{260}$ ignores the fact that virtually the same assessment is made in passive euthanasia. The objection that disabled existence can be compared with ceasing to exist but not with never existing (so that existence might be worse than one but not the other) will again produce absurd distinctions between rubella and failed sterilisation plaintiffs. So, in exceptionally severe cases, the doctor's conduct does cause the plaintiff physical damage, that damage being the state of (physically) existing.

\section{(f) Reasonable steps to avoid physical damage}

Since the doctor's conduct may cause reasonably foreseeable physical damage to the plaintiff - the damage being disability, or else existence worse than nonexistence - the doctor owes the child a duty of care and must take reasonable steps to prevent that damage. The only way to prevent the damage is to prevent an unwanted disabled child from being born; hence that is the content of the duty. ${ }^{261}$ Reasonable steps to prevent the birth of an unwanted disabled child

\footnotetext{
${ }^{257}$ See also: Harriton v Stephens; Waller v James; Waller v Hoolahan [2004] NSWCA 93, [157] (Mason P).

${ }^{258}$ McKay v Essex Area Health Authority [1982] 1 QB 1166 (CA), 1193B (Griffiths LJ).

259 Penny Dimopoulos \& Mirko Bagaric, The Moral Status of Wrongful Life Claims, 32 COMMON LAW WORLD REV. 35, 58-60 (2003). See: Airedale NHS Trust v Bland [1993] AC 789; [1993] 1 All ER 821; Re a Ward of Court (1995) 50 BMLR 140; Re J (A Minor) [1990] 3 All ER 930; [1991] 2 WLR 140; Re C (A Minor) [1989] 2 All ER 782; Gardner; Re BWV [2003] VSC 173 [43] (obiter); Hunter Area Health Service v Marchlewski [2000] 51 NSWLR 268; [2000] NSWCA 294, [91] (obiter). Note that quality of life is measured objectively or externally (that is, by persons other than the patient), since in most cases the patient is permanently unconscious and hence cannot assess his own quality of life; though the point is still to determine what is in the patient's best interests.

${ }^{261}$ Note that the duty of care arises only where the disabled child is unwanted. If the disabled child is wanted, the doctor's conduct will have no bearing on whether the child exists (and suffers physical damage) - in which case there is no possibility of causing physical damage and hence no duty of care (unless on other grounds).
} 
would be the exercise of reasonable care and skill in providing diagnosis, advice, sterilisation or abortion; ${ }^{262}$ for reasonable care in these matters will reduce the chance of an unwanted disabled child being born (by increasing the chance of effective contraception or abortion), and thus reduce the risk of physical damage (disability) occurring. It would not, of course, be reasonable to provide misleading advice or to lobby for an abortion. Hence the duty in wrongful lifeproviding adequate diagnosis, advice, sterilisation or abortion-has the same content as in wrongful birth; ${ }^{263}$ though in wrongful life the duty is owed to the future child via the parents. ${ }^{264}$

\section{Damage, causation, remoteness and damages}

Where a duty of care is owed and breached, and a disabled child results, physical damage-disability, or existence worse than non-existence-is caused. That damage is of a reasonably foreseeable kind (being the very sort of thing that might result from failure to provide proper advice, diagnosis or treatment), as are the pain, suffering and disability costs that flow from it. ${ }^{265}$ Accordingly, the defendant is liable on normal principles for those costs. ${ }^{266}$

At this point, however, the 'non-existence' argument resurfaces. Damages must, as far as money can, place the plaintiff in the same position as if the negligence had not occurred. ${ }^{267}$ Thus, to determine the appropriate measure of damages (in a case where the plaintiff claims for pain, suffering and economic loss), one

\footnotetext{
${ }^{262}$ See: Rogers v Whitaker (1992) 175 CLR 479; (1992) 109 ALR 625.

${ }^{263}$ See: above, Part II.A.1.

264 In Harriton v Stephens; Waller v James; Waller v Hoolahan [2004] NSWCA 93, [25]-[28], Spigelman $\mathrm{CJ}$ held that because the relationship between the wrongful life plaintiff and the doctor is mediated through the parents, that relationship is insufficiently 'direct' to create a duty of care. This seems implausible: if a doctor advises a pregnant woman (who opposes abortion) to spend lots of time with people who recently contracted rubella, the resulting disabled child (who, but for the negligence, would have been born without disabilities) could plainly sue the doctor for negligence-meaning there is sufficient 'directness' of relationship in this case; yet the relationship is surely no less 'direct' in wrongful life. Note also that the parents need not be seen as somehow acting on behalf of the potential child (contra the apparent view of Spigelman CJ at [27]); one need only recognise that the information provided to the parents by the doctor will affect whether an unwanted disabled child comes into existence and so suffers physical damage (disability).

${ }^{265}$ Costs flowing from (caused by) the disability are those a non-disabled person in the same position as the plaintiff (same except for the disability) would not incur-for example, nursing costs. Comparison between the plaintiff and a non-disabled person is legitimate here, since one is merely asking what flows from the disability (and this involves considering what would happen with versus without the disability). Earlier it was asked what flows from the negligence. The appropriate comparison there is between disabled existence and never being born (non-existence), since these are what would happen with versus without the negligence.

266 See: Overseas Tankship (UK) Ltd v Miller Steamship Co Pty Ltd (The Wagon Mound (No2)) [1967] 1 AC 617; [1967] ALR 97; Mahony v J Kruschich (Demolitions) Pty Ltd (1985) 156 CLR 522; (1985) 59 ALR 722 .

${ }^{267}$ Livingstone v Rawyards Coal Co (1880) 5 App Cas 25, 39 (Lord Blackburn); Lee Transport Co. Ltd. v. Watson (1940) 64 CLR 1, 13-14 (Dixon J); Butler v Egg and Egg Pulp Marketing Board (1966) 114 CLR 185, 191; [1966] ALR 1025; Todorovic v Waller (1981) 150 CLR 402; (1981) 37 ALR 481, 486 (Gibbs CJ and Wilson J), 510 (Mason J), 527-8 (Brennan J); Haines v Bendall (1991) 172 CLR 60, 63; 99 ALR 385, 386 (Mason CJ, Dawson, Toohey and Gaudron JJ); Manser v Spry (1994) 181 CLR 428; (1994) 124 ALR 539, 543 (Mason CJ, Brennan, Dawson, Toohey and McHugh JJ).
} 
determines in what respects the plaintiff's actual state involves additional pain, suffering or economic loss as compared with the hypothetical state he would have been in had the negligence not occurred; and one then determines an amount of money to compensate for that additional pain, suffering or economic loss. Put another way, "placing the plaintiff in the same position as if the negligence had not occurred' means the plaintiff's actual level of pain, suffering and economic loss, when combined with the award of damages, should be no worse from the (reasonable) plaintiff's point of view than the level of pain, suffering and economic loss in the hypothetical situation where the negligence does not occur. Inevitably, then, in wrongful life one must compare the plaintiff's actual state with a hypothetical state of non-existence (since non-existence is the state he would be in had the negligence not occurred); and it may be objected that this comparison is impossible, so that no damages can be awarded. ${ }^{268}$

There is no impossibility, however. A nonexistent person incurs no pain, suffering or economic loss; a wrongful life plaintiff does. So a wrongful life plaintiff's actual state involves additional pain, suffering and economic loss (such as disability costs) as compared with the hypothetical state he would have been in had the negligence not occurred; hence one can then determine, in the usual way, an amount to compensate for that additional pain, suffering and economic loss. Put another way, one should ensure the plaintiff's actual level of pain, suffering and economic loss, when combined with the award of damages, is no worse from the (reasonable) plaintiff's point of view than the level of pain, suffering and economic loss that occurs in the hypothetical state of non-existence (namely, no pain, suffering or economic loss). Again, damages for pain, suffering and economic loss can thus be calculated in the normal way, and indeed will be much the same as if the hypothetical situation involved a healthy, living plaintiff who likewise suffers no negligently caused pain, suffering or economic loss. Importantly, however, the wrongful life plaintiff's level of earnings and earning capacity, even if they are precisely zero, will never be worse than zero; hence, in terms of economic loss, the plaintiff could not recover for loss of earnings or loss of earning capacity-merely for economic losses taking the form of expenditure, such as disability costs.

Could the wrongful life plaintiff also recover upbringing costs (which are gratuitous care costs and thus treated as a form of economic loss suffered by the plaintiff $\left.^{269}\right)$ ? If the plaintiff's claim is based on mere disability, rather than on existence being worse than non-existence, then the defendant is not liable for upbringing costs, since upbringing costs are not caused by the physical damage (disability) and so are not consequential loss. Put another way, upbringing costs result from the plaintiff's very existence, hence are not consequential upon the physical damage complained of (disability), and so cannot be recovered.

\footnotetext{
268 See: Harriton v Stephens; Waller v James; Waller v Hoolahan [2004] NSWCA 93, [214]-[232] (Ipp JA).

${ }^{269}$ See: Cattanach v Melchior (2003) 199 ALR 131; [2003] HCA 38, [48] (Gummow and McHugh JJ), [276] (Callinan J); Griffiths v Kerkemeyer (1977) 139 CLR 161; (1977) 15 ALR 387.
} 
However, if the plaintiff's claim is based on existence being worse than nonexistence, the physical damage is not disability but existence itself (in a severely disabled state). Consequential damage-for which the defendant is liable-would then include all foreseeable damage flowing from that existence: pain, suffering, disability costs and upbringing costs. Damages in such a case should allow for sufficient care and treatment to ensure the child's life will be no worse than non-existence (the state he would be in but for the negligence).

In short: where the child is disabled (to any degree), the doctor is liable for pain, suffering, and disability costs. Where the child's life is worse than nonexistence, the doctor is liable for pain, suffering, disability and upbringing costs.

\section{Offsetting benefits and harms}

On normal principles, financial benefits caused by the negligence are, except for gifts or insurance payouts, offset against financial costs. ${ }^{270}$ Benefits gained through legislation may reduce damages, depending on statutory intention. ${ }^{271}$ In wrongful life, the negligence causes the child's existence, hence also causes any financial benefits existence may bring. Thus, disability and upbringing costs would be reduced according to any financial benefits the plaintiff will likely receive through employment and, depending on statutory intention, welfare benefits. For mild disabilities, expected benefits would often offset financial losses to zero.

It may be objected here that since a living person, no matter how badly disabled, can receive welfare benefits, whereas a nonexistent person cannot, therefore a living person is necessarily economically better off than a nonexistent personbetter off than zero-so that the wrongful life plaintiff would not be entitled to any damages for economic loss (such as disability or upbringing costs). In response, however, the fact that the negligence causes some economic benefits does not entail that those benefits completely offset the plaintiff's economic losses. ${ }^{272}$ If the plaintiff's economic losses (the costs of the disability and, in some cases, upbringing) exceed what the plaintiff does or can gain through employment and welfare, then the plaintiff suffers an overall economic loss and hence is economically worse off than zero as a result of the negligence: the plaintiff will always remain, as it were, 'in the red' (whereas a nonexistent person would suffer no such overall loss). So the objection fails to show a living person is necessarily economically better off than zero, and indeed merely restates the point, already conceded, that because the earnings and earning capacity of a living person will never be worse than zero, a wrongful life plaintiff could not recover damages for loss of earnings or loss of earning capacity.

\footnotetext{
270 National Insurance Co of New Zealand v Espagne (1961) 105 CLR 569, 573 (Dixon CJ); [1961] ALR 627.

271 National Insurance Co of New Zealand v Espagne (1961) 105 CLR 569; [1961] ALR 627; Manser v Spry (1994) 181 CLR 428; (1994) 124 ALR 539, 543-5 (Mason CJ, Brennan, Dawson, Toohey and McHugh JJ).

272 So much was assumed in Public Trustee v Zoanetti (1945) 70 CLR 266.
} 
Finally, the breach of duty in wrongful life-failure to provide adequate diagnosis, advice or sterilisation - may benefit the plaintiff overall, since the breach brings with it the emotional and other benefits of existence, and these may in some sense outweigh the costs of the disability. Similarly, the breach in wrongful birth may benefit the plaintiffs overall, since the breach brings with it the emotional benefits of a child, and these may in some sense outweigh the costs of pregnancy and upbringing. However, as Cattanach made clear, emotional benefits do not negate liability, and do not reduce damages for pain, suffering, or economic loss. $^{273}$

\section{$4 \quad$ Pure economic loss and wrongful life}

If, contra the above, wrongful life involves no physical damage, damages might still be recovered through the principles governing pure economic loss. If the doctor's conduct causes the birth of a child (healthy or disabled), the child will suffer economic loss: upbringing costs and, if disabled, disability costs. The Perre factors are satisfied as for wrongful birth,except that there is no 'known reliance' (the unborn plaintiff cannot possibly rely on anything). Given that all the factors the plaintiff possibly can satisfy are satisfied, a duty is most likely owed to the child to prevent economic loss. Reasonable steps to prevent such loss would again involve reasonable care and skill in providing the parents with diagnosis, advice, ${ }^{274}$ sterilisation or abortion; for this reduces the likelihood that the unwanted child will be born and suffer economic loss. If reasonable care is not taken, and as a result the child (healthy or disabled) is born, the doctor will be liable for upbringing costs, including, if the child is disabled, disability costs. Liability would then be offset as for consequential loss, so that in the case of a healthy or mildly disabled child financial losses would likely be offset to zero.

Thus, while a claim for pure economic loss precludes damages for pain and suffering, it would potentially allow a disabled plaintiff to recover upbringing costs, which (as argued) could not be recovered in a claim for consequential loss.

\section{Are There Sound Policy Arguments Against Recovery?}

\section{$1 \quad$ Contravening the sanctity of life}

Allowing wrongful life claims-in particular, imposing a duty to prevent the unwanted disabled child's birth-has been said to contradict the sanctity of human life. ${ }^{275}$

\footnotetext{
273 Cattanach v Melchior (2003) 199 ALR 131; [2003] HCA 38, [90] (McHugh and Gummow JJ), [173] (Kirby J), [297]-[298] (Callinan J).

${ }^{274}$ See: Rogers v Whitaker (1992) 175 CLR 479; (1992) 109 ALR 625.

275 McKay v Essex Area Health Authority [1982] 1 QB 1166 (CA), 1180G (Stephenson LJ), 1188B-C (Ackner LJ); Edwards v Blomeley [2002] NSWSC 460, [119]; Harriton v Stephens [2002] NSWSC 461, [71]; Waller v James [2002] NSWSC 462, [66]; Harriton v Stephens; Waller v James; Waller v Hoolahan [2004] NSWCA 93, [23] (Spigelman CJ), [303], [314], [348] (Ipp JA).
} 
This seems, however, to be another invalid slide from general values to a particular legal conclusion. ${ }^{276}$ If 'sanctity of life' means that preventing birththrough abortion, say-is in general immoral, then this is too controversial to be given legal force; moreover Cattanach showed there can be a duty to prevent the birth of unwanted children. If 'sanctity of life' means human life must always be judged better than non-existence (just as some think a healthy child must always be judged a 'blessing'), then this contradicts common sense and the passive euthanasia cases. If 'sanctity of life' means courts should nevertheless pretend human life is always better than non-existence, then it is not clear why courts should entertain a falsehood, particularly where this prevents compensation on normal principles; the court should rather award damages to ensure the child's existence is not worse than non-existence. At any rate, most wrongful life claims would be brought on the basis of mere disability, or, failing that, pure economic loss; and in these cases there is no suggestion that the child's existence is worse than non-existence.

Even if wrongful life actions did at some level infringe the sanctity of life, they would at a deeper level uphold it; for the law would in effect be saying that it values the lives of the disabled enough to ensure they can recover the cost of the care and treatment they deserve. ${ }^{277}$

\section{$2 \quad$ Offending the disabled}

To accept that disabled existence might be worse than non-existence would, it is said, 'be offensive' to disabled people, ${ }^{278}$ reducing their 'self esteem' and standing in society. ${ }^{279}$

This objection does not apply to claims brought on the basis of mere disability or pure economic loss, since in these cases there is no suggestion that the child's existence is worse than non-existence. Further, common sense and the passive euthanasia cases show severely disabled existence can be worse than nonexistence; normal principles should not be overturned merely because some people find this reality offensive. Also, a plaintiff claiming on the basis that his existence is worse than non-existence evidently believes this is so, if he is capable of understanding the matter at all; hence a court allowing the claim merely repeats what the plaintiff already believes, or asserts what he cannot understand.

\footnotetext{
276 See: Cattanach v Melchior (2003) 199 ALR 131; [2003] HCA 38, [77] (McHugh and Gummow J) (rejecting such inferences).

Cf. Harriton v Stephens; Waller v James; Waller v Hoolahan [2004] NSWCA 93, [124] (Mason P): 'It is one of the hallmarks of a compassionate society that care and treatment is made available to the severely disabled. To suggest that [wrongful life plaintiffs] are somehow impugning life itself by seeking just recompense for even the cost of care is quite irrational, indeed disturbing.'

${ }^{278}$ Edwards v Blomeley [2002] NSWSC 460, [75]

279 Edwards v Blomeley [2002] NSWSC 460, [119]; Harriton v Stephens [2002] NSWSC 461, [71]; Waller v James [2002] NSWSC 462, [66].
} 


\section{Appeals to the afterlife}

Those who believe the harms of this life will be outweighed by the joys of an afterlife would evidently deny that non-existence is ever worse than existence (at least in the very long run). Thus, it is said, for courts to allow claims based on existence being worse than non-existence would adjudicate the afterlife issue in favour of non-believers; and, as 'a worldly court' cannot do this-it must remain neutral—such claims must be disallowed. ${ }^{280}$

Again, this objection gives no reason to disallow claims brought on the basis of mere disability or pure economic loss, since there is no suggestion in such cases that the plaintiff's existence is worse than non-existence. In any case, to use unreal speculations about the fate of the dead as an excuse to ignore the very real needs and suffering of the living is manifestly unjust. If such speculations were allowed, the following would always be a good defence: 'Yes, Your Honour, I have negligently caused the plaintiff all manner of economic loss in this life. But he may receive extra riches in heaven to compensate! To allow recovery of damages would be to decide the 'extra riches in heaven' issue in favour of nonbelievers; and this a worldly court cannot do. ${ }^{281}$ The sane option is, plainly, to ignore such speculations. Tort law deals with this life, not the next life; and so if this life, considered in itself, is worse than non-existence, then compensation should be payable subject to normal principles.

\section{$4 \quad$ Actions against parents}

If wrongful life claims were accepted, the child, it is said, could sue not only the doctor but the mother, 'in the event that the mother was perceived to act unreasonably' in failing to abort; this could cause substantial 'disturbance of family life'. ${ }^{282}$ However, as noted in wrongful birth, courts are loath to find that failure to have an abortion is unreasonable. Moreover the argument, if accepted, would merely prevent children suing mothers; it would not prevent children suing doctors. ${ }^{283}$

\section{$5 \quad$ Trivial disability}

Griffiths LJ in McKay noted the difficulty of specifying 'how gravely deformed' the plaintiff must be before a wrongful life claim would be possible. ${ }^{284}$

The arguments presented here avoid this difficulty: a wrongful life action is possible wherever an unwanted child is born through medical negligence and suffers a malformation of brain or body that results in pain, suffering or economic loss. A mere constitutional weakness-for example, having weaker arms

\footnotetext{
${ }^{280}$ Edwards v Blomeley [2002] NSWSC 460, [75].

${ }^{281} C f$. Edwards v Blomeley [2002] NSWSC 460, [75] (the logic appears parallel).

282 Edwards v Blomeley [2002] NSWSC 460, [119]; Harriton v Stephens [2002] NSWSC 461, [71]; Waller v James [2002] NSWSC 462, [66]; see also McKay v Essex Area Health Authority [1982] 1 QB 1166 (CA), 1181A-B (Stephenson LJ).

${ }^{283}$ Harriton v Stephens; Waller v James; Waller v Hoolahan [2004] NSWCA 93, [139] (Mason P).

${ }^{284}$ McKay v Essex Area Health Authority [1982] 1 QB 1166 (CA), 1193C-D (Griffiths LJ).
} 
or eyes than average-is not, of course, physical damage; but a slightly deformed ear would be, and if it causes pain, suffering or economic loss (such as medical costs), then it could ground an action for wrongful life.

Wrongful life actions would not, therefore, be restricted to the severely disabled: even the trivially disabled could claim. It may be objected that this is absurd. But that is hardly clear. Normal principles place no lower limit on the degree of physical damage required to ground an action in negligence-one could sue, for example, for the minor pain and suffering of a stubbed toe-and so it is to be expected that a case for wrongful life based on normal principles will likewise place no lower limit on the necessary degree of damage. There is no more injustice or absurdity here than in other categories of negligence. Further, trivial disabilities will produce trivial damages, since such disabilities will cause little pain and suffering and the plaintiff's likely earnings will offset financial losses to zero. This too is neither unjust nor absurd.

There does remain the issue of 'how gravely deformed' a plaintiff must be before his existence would be judged worse than non-existence (so as to allow recovery of upbringing costs). This issue, while difficult, is no more difficult than in passive euthanasia, and should be approached by courts in the same cautious and compassionate way. ${ }^{285}$ In practice the issue may be easier to decide, since the outcome concerns damages rather than life or death.

\section{Conclusion}

Recovery of damages for wrongful life is counterintuitive, but a careful application of normal principles shows this is the correct position. Once the "nonexistence' argument is exposed as irrelevant (since it incorrectly focuses on the plaintiff's life as a whole, rather than on negligent causation of physical damage), the way to recovery is clear. Typically in wrongful life, damages should be recoverable for pain, suffering, and disability costs, with disability costs offset according to income the plaintiff will receive through employment and, perhaps, statutory welfare benefits. In extraordinary cases where existence is worse than non-existence, the plaintiff could also recover upbringing costs. However, since wrongful life will not normally allow recovery of upbringing costs-whereas wrongful birth normally will-the disabled child and parents would need to bring a combined action for both birth torts in order to secure full compensation..

\footnotetext{
285 See: Airedale NHS Trust v Bland [1993] AC 789; [1993] 1 All ER 821; Re a Ward of Court (1995) 50 BMLR 140; Re J (A Minor) [1990] 3 All ER 930; [1991] 2 WLR 140; Re C (A Minor) [1989] 2 All ER 782; Gardner; Re BWV [2003] VSC 173 [43] (obiter); Hunter Area Health Service v Marchlewski (2000) 51 NSWLR 268; [2000] NSWCA 294, [91] (obiter).
} 